\title{
Economic effect of reducing nitrogen and phosphorus mass balance on Wisconsin and Québec dairy farms
}

\author{
D. Pellerin, ${ }^{*}$ E. Charbonneau, ${ }^{*}$ L. Fadul-Pacheco, ${ }^{*}$ O. Soucy, $\dagger$ and M. A. Wattiaux ${ }^{1}$ \\ *Département des Sciences Animales, and \\ †Département de Phytologie, Université Laval, Québec, QC, Canada G1V 0A6 \\ ‡Department of Dairy Science, University of Wisconsin, Madison 53706
}

\begin{abstract}
Our objective was to explore the trade-offs between economic performance (farm net income, FNI) and environmental outcomes (whole-farm $\mathrm{P}$ and $\mathrm{N}$ balances) of dairy farms in Wisconsin (WI; United States) and Québec (QC; Canada). An Excel-based linear program model (N-CyCLES; nutrient cycling: crops, livestock, environment, and soil) was developed to optimize feeding, cropping, and manure management as a single unit of management. In addition to FNI, $\mathrm{P}$ and $\mathrm{N}$ balances model outputs included (1) the mix of up to 9 home-grown and 17 purchased feeds for up to 5 animal groups, (2) the mix of up to 5 crop rotations in up to 5 land units and c) the mix of up to 7 fertilizers (solid and liquid manure and 5 commercial fertilizers) to allocate in each land unit. The model was parameterized with NRC nutritional guidelines and regional nutrient management planning rules. Simulations were conducted on a typical WI farm of 107 cows and 151 ha of cropland and, a Southern QC farm of 87 cows and 142 ha of cropland and all results were expressed per $\mathrm{kg}$ of fat- and protein-corrected milk (FPCM). In absence of constraints on $\mathrm{P}$ and $\mathrm{N}$ balances, maximum FNI was 0.12 and $0.11 \$ / \mathrm{kg}$ of FPCM for WI and QC, respectively, with $\mathrm{P}$ and $\mathrm{N}$ balances of 1.05 and 14.29 $\mathrm{g} / \mathrm{kg}$ of FPCM in WI but 0.60 and $15.70 \mathrm{~g} / \mathrm{kg}$ of FPCM in QC. The achievable reduction (balance at maximum FNI minus balance when the simulation objective was to minimize $\mathrm{P}$ or $\mathrm{N}$ balance) was 0.31 and $0.54 \mathrm{~g}$ of $\mathrm{P} /$ $\mathrm{kg}$ of FPCM (29 and $89 \%$ reduction), but 2.37 and 3.31 $\mathrm{g}$ of $\mathrm{N} / \mathrm{kg}$ of FPCM (17 and $24 \%$ reduction) in WI and QC, respectively. Among other factors, differences in animal unit per hectare and reliance on biological $\mathrm{N}$ fixation may have contributed to lower achievable reductions of whole-farm balances in WI compared with QC. Subsequent simulations to maximize FNI under increasing constraints on nutrient balances revealed
\end{abstract}

Received September 11, 2016.

Accepted June 6, 2017.

${ }^{1}$ Corresponding author: wattiaux@wisc.edu that it was possible to reduce $\mathrm{P}$ balance, $\mathrm{N}$ balance, and both together by up to $33 \%$ without a substantial effect on FNI. Partial reduction in $\mathrm{P}$ balance reduced $\mathrm{N}$ balance (synergetic effect) in WI, but increased $\mathrm{N}$ balance (antagonistic effect) in QC. In contrast, reducing $\mathrm{N}$ balance increased $\mathrm{P}$ balance in both regions, albeit in different magnitudes. The regional comparison highlighted the importance of site-specific conditions on modeling outcomes. This study demonstrated that even when recommended guidelines are followed for herd nutrition and crop fertilization, the optimization of herd feeding, cropping, and manure spreading as a single unit of management may help identify management options that preserve FNI, while substantially reducing whole-farm nutrient balance.

Key words: whole-farm nutrient balance, phosphorus, nitrogen, linear programming

\section{INTRODUCTION}

The intensification of crop-livestock systems in parts of the world during the 20th century has contributed to substantial alteration of the earth biogeochemical cycles of P and N (Bouwman et al., 2013). Ammonia volatilization contributes to eutrophication and acidification of natural ecosystems and nitrous oxide contributes substantially to agricultural greenhouse gases emissions. In addition, nitrate and phosphates in leachates and runoffs from fields impair water resources (fresh waters, ground waters, and coastal waters). The risk of undesirable environmental impacts are heightened when importation of large amounts of $\mathrm{P}$ and $\mathrm{N}$ is combined with relatively low conversion efficiencies into crops and livestock products, leading to large whole-farm balances (Hristov et al., 2006; Huhtanen et al., 2011; Cela et al., 2014). Proper manure management may lower the risk of environmental degradation (Powell et al., 2002; Koelsch, 2005; Gourley et al., 2012) and fertilizer expenses. Consequently, nutrient management plans (NMP) are designed to make efficient use of manure nutrients, they minimize risks of nutrient leakages to the environment, and thus they 
provide an opportunity to increase efficiency of wholefarm nutrient utilization. Although certified NMP address temporal and spatial distribution of manure and fertilizers to the fields, they do not address feeding practices and the importation of feeds, which may be a major source of nutrient inputs on dairy farms (Powell et al., 2002; Spears et al., 2003a,b). Thus NMP and whole-farm nutrient balances are complementary tools with the former addressing primarily internal cycling of nutrients within the farm and the latter addressing primarily input-output relationships across farm boundaries. In short, a whole-farm nutrient balance is a diagnostic tool (Koelsch, 2005; Schils et al., 2007), whereas a NMP is a prescriptive tool. Few attempts have been made to combine these 2 types of tools into a farm-level economic decision-making aid. Europeans have a long history of using modeling techniques to explore economic and environmental outcomes associated with changes in management practices and legislative policies (Berentsen and Giesen, 1995; Klootwijk et al., 2016). Other modeling efforts have focused on reduction of whole-farm nutrient balances (Wang et al., 2000) or optimization of manure allocation (Giasson et al., 2002). Additionally, the integrated farm system model (Rotz et al., 2015) has been used to explore P precision feeding (Ghebremichael et al., 2007). However in the North American production context, none of the existing models have considered feeding strategies (selection of feed ingredients), cropping strategies (selection of crop rotations), fertilization plan (selection of fertilizers) and on-farm manure management (manure allocation) as a single unit of management subject to optimization. By design, such modeling capacity was built in N-CyCLES (nutrient cycling: crops, livestock, environment and soils), an Excel-based linear program presented here. Our objective was to use N-CyCLES to explore management options and develop model estimates of change in farm net income (FNI) when resources are allocated to reduce nutrient balances and the 4 aforementioned areas of management are optimized as a single unit of management. The data were from medium-size conventional (i.e., nongrazing and nonorganic) dairy systems of Wisconsin (WI; United States) and Québec (QC; Canada). These locations were selected based on the importance of dairy to the local economy, distinctive features allowing for meaningful comparisons, and availability of reliable data.

\section{MATERIALS AND METHODS}

\section{Model Description}

Overview. N-CyCLES is a linear optimization model that runs with the add-in solver of Microsoft
Excel (Microsoft Corp., Redmond, WA). Technical documentation can be found at https://kb.wisc.edu/ dairynutrient/page.php?id=60349. The model may be set to meet 1 of 3 objectives: to maximize FNI, to minimize whole-farm $\mathrm{P}$, or to minimize whole-farm $\mathrm{N}$ balance. The model includes economic parameters and describes the imports and exports of N, P, and K across farm boundaries as described in Figure 1. Farm net income is calculated as the difference between incomes and expenses. Whole-farm $\mathrm{P}$ and $\mathrm{N}$ balances are calculated by difference between farm-gate imports and exports. Sources of imports accounted for include purchased feeds and fertilizers and in the case of $\mathrm{N}$, atmospheric deposition (NADP, 2016), and biological N-fixation (Koelsch and Lesoing. 1999). Sources of exports accounted for include milk and animal sold, manure exported, and crop sold. Quantifying potential losses of $\mathrm{P}$ and $\mathrm{N}$ to surface and ground water were outside the scope of the model. However, cycling of nutrients within the farm is described by input-output relationships of animal groups in the herd and inputoutput relationships of land units defined as groups of fields with distinct characteristics influencing NMP. In $\mathrm{N}-\mathrm{CyCLES}$, manure nutrient outputs from the herd may serve as inputs to the crops and feed nutrient outputs from the crops may serve as nutrient inputs to the herd (Figure 1). The model accommodates for the combination of on-farm and off-farm nutrient resources to meet both animal and crop requirements. In the model, ration formulation, crop rotation (succession of crops on a piece of land over time), purchase of feed, purchase of fertilizers, and allocation of manure $\mathrm{P}$ and $\mathrm{N}$ to the land are considered a single integrated unit of management. In other words, to meet a specific goal, the optimization algorithm takes into account simultaneously the allocation of home-grown and purchased feeds to meet herd nutritional requirements, the allocation of the land to crops grown in rotations, and the allocation of manure and purchased fertilizers to meet $\mathrm{P}$ and $\mathrm{N}$ recommendations of the crops. The unit of time is the year and the model assumes that the production system is essentially at a steady state. Model outcomes may be assessed on a per-hectare basis (nutrient balance), per-cow basis (FNI), per-year basis, or per kilogram of fat- and protein-corrected milk (FPCM; IDF, 2015).

Optimized Variables. In contrast to milk and animals sold, the sale of harvested crops is an optimized income variable in N-CyCLES. Thus the decision to grow crops for sale (i.e., export) or to use harvested crops as home-grown feed is a model outcome. Expense variables under optimization included purchased feeds, purchased fertilizers, the cost of production and storage of home-grown feeds, and manure spreading. User-defined fixed costs (labor, depreciation, interest, tax, and 
insurance) and variable costs (breeding fee, veterinary expenses, bedding, and supplies) are not subjected to optimization. The optimized variables used to minimize $\mathrm{P}$ or $\mathrm{N}$ balance include crop sold, purchased feeds, and purchased fertilizers. In N-CyCLES manure is used preferentially as a source of plant nutrient because on-farm manure nutrient production has no purchased cost, and the cost of manure export is greater than the cost of spreading manure in the field farthest away from the storage unit. However, the model accommodates for the possibility of exporting manure nutrient off the farm (as in the case of high animal density) but does not simulate barter transactions.

Feeds and Diets. Available feeds include 9 cropderived home-grown feeds and 17 purchased feeds (Appendix Table A1). Field and storage losses of forage, storage losses of concentrates and minerals, and if necessary change in inventory of up to 3 silages are user defined. In addition to being used as feed ingredients for ration formulation, feeds in the home-grown category can be sold or purchased. Dietary guidelines are described for up to 5 animal groups including 1 or 2 lactating groups and a user-selected choice for 3 nonlactating groups: (1) far-off dry cows, pre-fresh cows and replacement heifers or (2) dry cows, heifers $<1$ yr old and heifers $\geq 1$ yr old. For each group, the NRC (2001) equations are used to calculate DMI of animals in each group as well as net energy of lactation (discounted for level of production; $\mathbf{N E}_{\mathrm{Lp}}$ ), RUP and RDP values of each feed ingredient, and diets for each group. Adequate dietary composition (DM basis) are described with minima and maxima for $\mathrm{NE}_{\mathrm{Lp}}, \mathrm{RDP}$, and available $\mathrm{P}, \mathrm{Mg}, \mathrm{K}, \mathrm{Ca}, \mathrm{Na}, \mathrm{Cl}$, and total $\mathrm{S}$; minima for $\mathrm{NDF}$, forage NDF, and RUP; and maxima for ether extract and NFC.

Manure and Fertilizer. Sources of crop nutrients $(\mathrm{N}, \mathrm{P}$, and $\mathrm{K}$ ) included 5 commercial fertilizers (Appendix Table A2) and 2 on-farm manure types (solid and liquid). For each animal group, the amount of manure excreted was calculated according to ASAE (2005) and Nennich et al. (2005). Nutrient excretions in manure are obtained by subtracting amounts in animal products (milk and BW gain) from dietary consumption. Total on-farm production of nutrients is calculated as manure excretion plus mineral nutrients in feed refusals. Ammonia volatilization from manure depends upon the user-defined mode of manure collection and storage. Furthermore, manure type and mode of fieldapplication influence availability coefficients used to calculate plant available N, P, and K (Laboski et al., 2006; CRAAQ, 2010a). Cost of manure spreading is user-defined and based upon total amount to spread, transportation distance, and mode of application as described by Massey (2008).

Crops and Rotations. In N-CyCLES, available cropland can be sub-divided in up to 5 land units. By default, land unit A included the fields highest in soil $\mathrm{P}$ test and highest $\mathrm{OM}$, whereas land unit E included

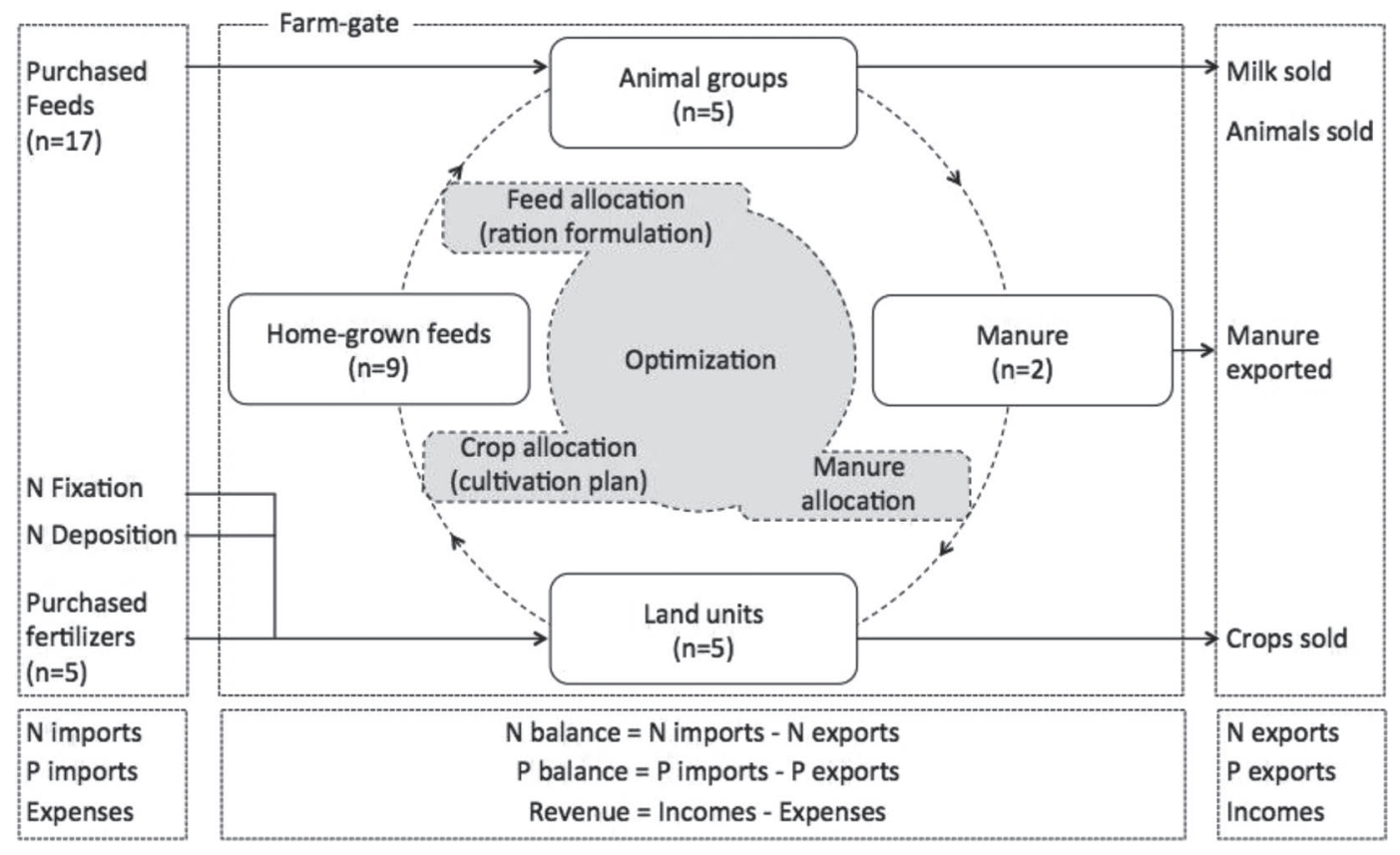

Figure 1. Overview of N-CyCLES (nutrient cycling: crops, livestock, environment, and soils) describing the N and P imports and exports (solid lines) to establish balance across the boundary of the livestock-crop component of a farm (dotted line), the resources whose allocations are subject to simultaneous optimization (gray area), and the cycling of nutrients within the boundary (dashed line). 
fields with the lowest soil P test and lowest OM (Saam et al., 2005). Up to 5 crop rotations can be allocated to each land unit. Yields of perennial crops (legumes and grass) vary with stand longevity and yields of corn are adjusted for crop rotation effect (Posner et al., 2008). The $\mathrm{P}$ and $\mathrm{K}$ needs of crops in the rotations vary with soil nutrient content $(\mathrm{P}$ and $\mathrm{K})$, whereas $\mathrm{N}$ needs of nonlegume crops vary with soil $\mathrm{OM}$ and yr 1 and yr 2 $\mathrm{N}$ credit from legumes (Laboski et al., 2006; CRAAQ, 2010a). Fertilization plan relies on on-farm nutrient resources or purchased fertilizers with a user-defined allowable excess application rate of $\mathrm{N}, \mathrm{P}$, and $\mathrm{K}$ in each land unit, allowing adjustments for differences in regional policies.

Model Outcomes. Given the desired objective, the farm characteristics (herd size and acreage of crop land) and model constraints related to herd nutrition and crop fertilization, N-CyCLES searched the space of feasible resources allocation, and when a solution exists, the model (1) determines the mix of home-grown feeds and purchased feeds that meet dietary guidelines of each animal group, (2) selects the crop rotation (or combination thereof) for each land unit; and (3) determines manure allocation and purchased fertilizers to apply in each land unit. Thus N-CyCLES considers feed allocation, choices of crops, fertilizer purchase, and manure allocation as a single unit of management, and in that way it optimizes feeding practices, rotation plan, and nutrient management together rather than as distinct and separate areas of farm management.

\section{Regional Cases}

Two regional cases were developed to describe a typical farm of southern WI $\left(43^{\circ} \mathrm{N} ; 89^{\circ} \mathrm{W}\right)$ and southwest QC $\left(45^{\circ} \mathrm{N} ; 72^{\circ} \mathrm{W}\right)$. Farm descriptors and economic inputs including feed prices, fertilizer prices, and milk prices were from a variety of sources and for the most part with average data centered around 2010. Farm characteristics and economic inputs for WI were from the "Agfa" database managed by the University of Wisconsin-Madison Center for Dairy Profitability (CDP, 2009, 2011). Farm characteristics and economic inputs for QC were from the Agritel Database summarized by the "Centre de référence en Agriculture et en Agroalimentaire du Québec" (CRAAQ, 2011a).

Herd. For WI, cow number was 107, which was near the 2010 state-wide average of 112.9 cows per herd (USDA, 2011). For QC, cow number was 87, which was greater than the 2010 provincial average of 57.1 (Valacta, 2011). Milk performance, milk fat content, and milk protein content for WI and QC were 9,962 and $8,695 \mathrm{~kg} /$ cow per yr, 3.60 and $3.90 \%$, and 3.10 and $3.26 \%$, respectively, which led to FPCM of 8,847 and $8,131 \mathrm{~kg} /$ cow per yr for WI and QC, respectively. Calving interval was 13.9 and $14.3 \mathrm{mo}$ in WI and QC, respectively, and cow culling rate was $36 \%$ in both locations.

Main Economic Inputs. Feed prices, fertilizer prices, and average cost of production of each crop rotation are in Appendix Tables A1, A2 and A3, respectively. Milk prices, which have been highly variable in WI, but stable in QC (because of the quota system), were representative of the 2008-2012 periods. In WI, milk price was set at $0.374 \$ / \mathrm{kg}$ of FPCM $(36.01 \$ / \mathrm{hL}$, Gould, 2014). In QC, milk price was set at $0.72 \$ / \mathrm{kg}$ of FPCM $(73.27 \$ / \mathrm{hL})$. Average FPCM sold per farm, assuming $5 \%$ milk waste, was 946,631 and $707,573 \mathrm{~kg} /$ yr for WI and QC, respectively. Other incomes including mainly livestock sale were equivalent to 0.05 and $0.02 \$ / \mathrm{kg}$ of FPCM, whereas nonoptimized fixed and variable costs were 0.23 in WI, but 0.40 in $\mathrm{QC}$, due to slight but consistently higher costs associated with labor, taxes, insurance, depreciation, and interest.

$P$ and $N$ in Dairy Cow Rations. The herd in each regional case consisted of 2 groups of lactating cows (early and mid-late lactation), a group of dry cows, and 2 heifer groups ( $<1$ yr old and $\geq 1$ yr old). Dry matter intake for cows in early lactation group and in mid-late lactation group was 23.9 and $20.9 \mathrm{~kg} / \mathrm{d}$ for WI, but 22.1 and $19.6 \mathrm{~kg} / \mathrm{d}$ for QC. The maximum available P was set at $50 \%$ above the minimum. Thus the allowable range in available $\mathrm{P}$ (dietary DM basis) for early group and mid-late group was 0.28 to 0.42 and 0.23 to $0.34 \%$, respectively for WI, and 0.26 to 0.39 and 0.21 to $0.32 \%$, respectively for $\mathrm{QC}$. In the case of WI, minimum RUP was 5.7 and $5.0 \%$, and allowable range in RDP was 10.9 to $13.6 \%$ and 9.9 to $12.4 \%$, for early lactating group and mid-late group, respectively. In the case of $\mathrm{QC}$, minimum RUP was 5.4 and $4.7 \%$, and allowable range in RDP was 10.7 to $13.4 \%$ and 9.8 to $12.2 \%$, for early lactating group and mid-late group, respectively.

Land, Crops, and Rotations. The land base was 151.2 and 142.0 ha of cropland subdivided in 3 land units (A, C, and E) of equal size (50.4 and 47.3 ha) for WI and QC, respectively. Because of reported associative patterns between soil $\mathrm{P}$ test and distance from manure storage (Koelsch and Lesoing, 1999; Saam et al., 2005), land units A, C, and E were set at high, optimal, and low soil $\mathrm{P}$ test with hauling distances of $0.8,2.4$, and $7.2 \mathrm{~km}$, respectively, in both regional cases. A detailed description of rotations is presented in Appendix Table A3. Regional differences in cropping practices were reflected in part by production of barley grain and grass hay in QC, but not in WI. Allowable manure and fertilizer application in each land unit were set to comply with regional NMP policies and regulations (WIDATCP, 2014, for WI and MDDELCC, 2015, 
for QC). Also, regional differences in mode of manure application were accounted for assuming broadcasting for WI and spray bar misting for QC.

\section{Simulations}

Four main simulation steps were performed for each regional case. In the first step, achievable reduction (AR) in whole-farm $\mathrm{P}$ balance was determined as the difference in $\mathrm{P}$ balance when the model was solved to maximize FNI (MaxI) and when the model was solved to minimize $\mathrm{P}$ balance. The same approach was used to determine AR in whole-farm $\mathrm{N}$ balance. Then the model was solved for MaxI under the constraint of reducing $\mathrm{P}$ and $\mathrm{N}$ balance to $99.9 \%$ of their respective AR, thus leading to 3 base simulations including MaxI, MaxI at lowest $\mathrm{P}$ balance (MinP), and MaxI at lowest $\mathrm{N}$ balance (MinN). In the second step, the effects of partial reductions of whole-farm $\mathrm{P}$ balance were explored by solving the model for MaxI under the constraint to reduce $\mathrm{P}$ balance to (less or equal to) $12.5,25,33,50,75$, $87.5,93.75,96.875,98.438$, and $99.9 \%$ of its AR. In the third step, the effects of partial reduction of whole-farm $\mathrm{N}$ balance were explored using the same approach as in the second step. In the fourth step, the feasibility and effect of reducing the whole-farm $\mathrm{P}$ and $\mathrm{N}$ balances simultaneously were explored by adding 2 constraints to the MaxI base simulation, setting whole-farm balance ceilings for both nutrients at all combinations of the levels described above. Changes in FNI under increasing constraints on whole-farm $\mathrm{P}$ and $\mathrm{N}$ balances were plotted and solutions for the $33 \%$ reduction in $\mathrm{P}$ balance $(\mathbf{3 3 P}), 33 \%$ reduction in $\mathrm{N}$ balance $(\mathbf{3 3 N})$, and $33 \%$ reduction in both $(\mathbf{3 3 P} \mathbf{P} \mathbf{3 3 N})$ were tabulated as deviations from the MaxI solution. Finally, a sensitivity analysis was conducted to assess the effect of variability in feed $(+35$ or $-35 \%)$ and $(+25$ or $-25 \%)$ fertilizer prices on key model outcomes. All results are presented per kilogram of FPCM for consistency and convenience of cross-regional comparison.

\section{RESULTS}

\section{Net Income and Nutrient Mass Balances}

Table 1 presents results of base simulations for each regional case. The FNI, P balance, and $\mathrm{N}$ balance when income is maximized are presented in the MaxI column. In contrast, the FNI, $\mathrm{P}$ balance, and $\mathrm{N}$ balance under the objective of minimizing nutrient balances are presented as deviations from MaxI. As expected, FNI was the highest in the MaxI simulation, $\mathrm{P}$ balance was the lowest in the MinP simulation, and $\mathrm{N}$ balance was the lowest in the MinN simulation.

Wisconsin Case. Under MaxI, FNI was $0.12 \$ / \mathrm{kg}$ of FPCM $(116,331 \$ / \mathrm{yr})$, P balance was $1.05 \mathrm{~g} / \mathrm{kg}$ of FPCM $(997 \mathrm{~kg} / \mathrm{yr})$, and $\mathrm{N}$ balance was $14.29 \mathrm{~g} / \mathrm{kg}$ of FPCM $(13,523 \mathrm{~kg} / \mathrm{yr})$. The AR for P balance was 0.31 $\mathrm{g} / \mathrm{kg}$ of FPCM, a potential for $29 \%$ reduction, which equated to $291 \mathrm{~kg} / \mathrm{yr}$ of $\mathrm{P}$ ( $\mathrm{P}$ balance of 997 vs. 706 $\mathrm{kg} / \mathrm{yr}$ for MaxI and MinP, respectively). Although FNI was reduced substantially under MinP $(-0.08 \$ / \mathrm{kg}$ of FPCM), a partial reduction of $\mathrm{P}$ balance up to $33 \%$ of AR had a minimal effect $(-0.01 \$ / \mathrm{kg}$ of FPCM, see 33P; Table 1). More stringent restrictions, however, led to a rapidly increasing loss of FNI (Figure 2A). The AR for $\mathrm{N}$ balance was $2.37 \mathrm{~g} / \mathrm{kg}$ of FPCM, a potential for $17 \%$ reduction, which equated to $2,249 \mathrm{~kg} / \mathrm{yr}$ of $\mathrm{N}$ (N balance of 13,528 vs. $11,279 \mathrm{~kg} / \mathrm{yr}$ for MaxI and MinN, respectively). Although FNI was reduced substantially under min $\mathrm{N}(-0.06 \$ / \mathrm{kg}$ of FPCM), a partial reduction of $\mathrm{N}$ balance up to $33 \%$ of AR had essentially no effect

Table 1. Farm net income, $\mathrm{P}$ balance, and $\mathrm{N}$ balance obtained (A) from base simulations to maximize net income (MaxI), MaxI at minimum P balance (MinP), and MaxI at minimum $\mathrm{N}$ balance (MinN) and (B) from partial reduction in nutrient balance: $33 \%$ of the achievable reduction in $\mathrm{P}(33 \mathrm{P})$, in $\mathrm{N}(33 \mathrm{~N})$, and in both $\mathrm{P}$ and $\mathrm{N}$ together (33P-33N) for Wisconsin and Québec dairy farm cases

\begin{tabular}{|c|c|c|c|c|c|c|}
\hline \multirow[b]{2}{*}{ Regional case } & \multicolumn{3}{|c|}{ (A) Base simulations } & \multicolumn{3}{|c|}{ (B) Partial reduction in $\mathrm{P}$ and $\mathrm{N}$ balance } \\
\hline & MaxI & $\underset{\Delta^{1}}{\operatorname{MinP}}$ & $\underset{\Delta^{1}}{\operatorname{MinN}}$ & $\begin{array}{c}33 \mathrm{P} \\
\Delta^{1}\end{array}$ & $\begin{array}{c}33 \mathrm{~N} \\
\Delta^{1}\end{array}$ & $\begin{array}{c}33 \mathrm{P}-33 \mathrm{~N} \\
\Delta^{1}\end{array}$ \\
\hline \multicolumn{7}{|l|}{ Wisconsin } \\
\hline Net income, ${ }^{2} \$ / \mathrm{kg}$ of FPCM & 0.12 & -0.08 & -0.06 & -0.01 & 0.00 & -0.01 \\
\hline $\mathrm{P}$ balance, $\mathrm{g} / \mathrm{kg}$ of FPCM & 1.05 & -0.31 & -0.03 & -0.10 & 0.03 & -0.10 \\
\hline $\mathrm{N}$ balance, $\mathrm{g} / \mathrm{kg}$ of FPCM & 14.29 & 2.64 & -2.37 & -0.48 & -0.78 & -0.78 \\
\hline \multicolumn{7}{|l|}{ Québec } \\
\hline Net income, ${ }^{2} \$ / \mathrm{kg}$ of FPCM & 0.11 & -0.13 & -0.12 & 0.00 & -0.01 & -0.03 \\
\hline $\mathrm{P}$ balance, $\mathrm{g} / \mathrm{kg}$ of FPCM & 0.60 & -0.54 & 0.90 & -0.18 & 0.13 & -0.18 \\
\hline $\mathrm{N}$ balance, $\mathrm{g} / \mathrm{kg}$ of FPCM & 15.70 & 1.37 & -3.31 & 0.15 & -1.09 & -1.09 \\
\hline
\end{tabular}

${ }^{1} \Delta=$ simulation $_{\mathrm{i}}-$ MaxI, where $\mathrm{i}=\mathrm{MinP}$, MinN, 33P, 33N, or 33P-33N.

${ }^{2}$ Annual milk sold in Wisconsin and Québec was 946,631 and 707,399 kg/yr of fat- and protein-corrected milk (FPCM), respectively. 
A)

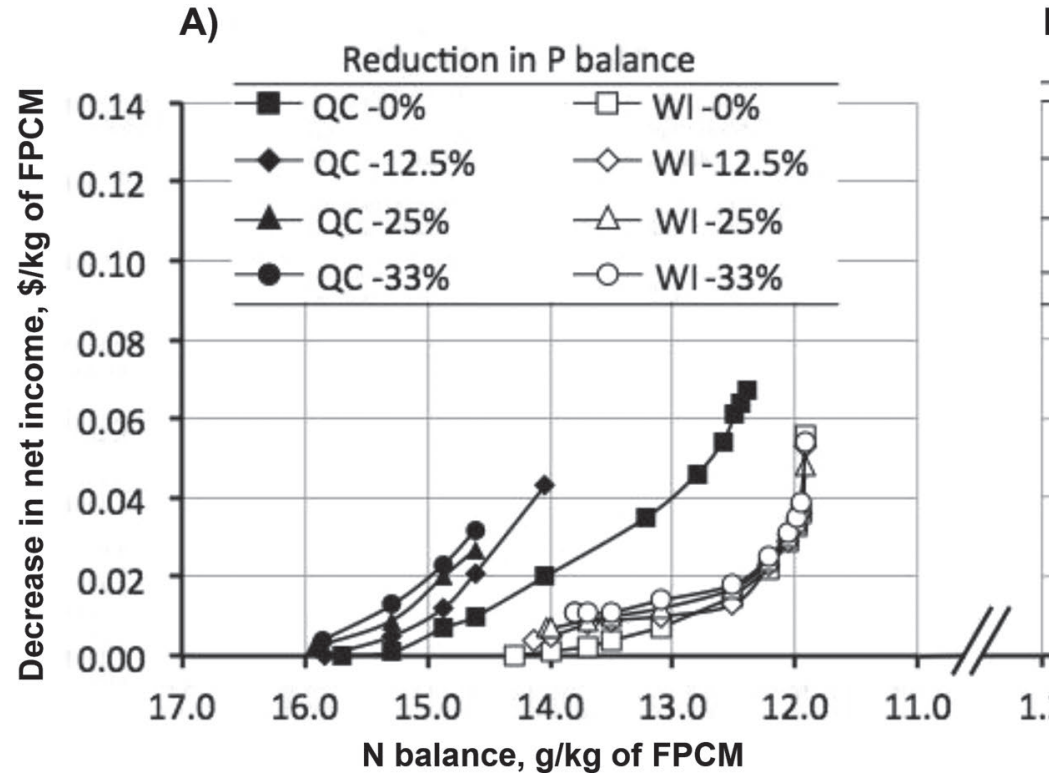

B) Reduction in $\mathrm{N}$ balance

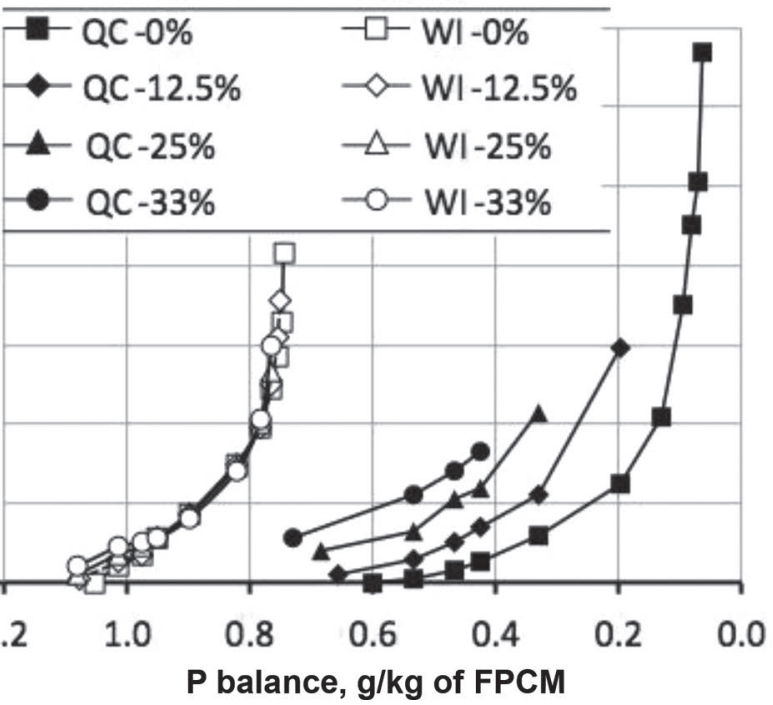

Figure 2. Decrease in farm net income with increasing reduction in (A) P balance and (B) N balance (data points from left to right within a line correspond to a decrease in balance of $0,12.5,25,33,50,75,87.5,93.75,96.875,98.438$, and $99.9 \%$ of achievable reduction) when $\mathrm{N}$ and $\mathrm{P}$ balance, respectively, were unrestricted (0\% reduction) or restricted by 12.5, 25, and 33\% for Wisconsin (WI) and Québec (QC) cases (note that fewer than 11 data points within a line reflected infeasible solutions with increasing restrictions in the whole-farm balance of both nutrients). $\mathrm{FPCM}=$ fat- and protein-corrected milk.

$(0.00 \$ / \mathrm{kg}$ of FPCM, see $33 \mathrm{~N}$; Table 1$)$. More stringent restrictions, however, led to a rapidly increasing loss of FNI (Figure 2B). Reduction in FNI was minimal with a $33 \%$ partial reduction in both $\mathrm{P}$ and $\mathrm{N}$ balances together $(-0.01 \$ / \mathrm{kg}$ of FPCM, see 33P-33N; Table 1$)$, and was of the same magnitude as when reducing $\mathrm{P}$ balance alone.

Québec Case. Under MaxI, FNI was $0.11 \$ / \mathrm{kg}$ of FPCM $(74,277 \$ / \mathrm{yr}), \mathrm{P}$ balance was $0.60 \mathrm{~g} / \mathrm{kg}$ of FPCM $(426 \mathrm{~kg} / \mathrm{yr})$, and $\mathrm{N}$ balance was $15.70 \mathrm{~g} / \mathrm{kg}$ of FPCM $(11,105 \mathrm{~kg} / \mathrm{yr})$. The AR for P balance was 0.54 $\mathrm{g} / \mathrm{kg}$ of FPCM, a potential for $89 \%$ reduction, which equated to $381 \mathrm{~kg} / \mathrm{yr}$ of P (P balance of $426 \mathrm{~kg} / \mathrm{yr}$ vs. $45 \mathrm{~kg} / \mathrm{yr}$ for MaxI and MinP, respectively). Although FNI was reduced dramatically under MinP $(-0.13$ $\$ / \mathrm{kg}$ of FPCM), a partial reduction of $\mathrm{P}$ balance up to $33 \%$ of AR had essentially no effect $(0.00 \$ / \mathrm{kg}$ of FPCM). More stringent restrictions, however, led to a rapidly increasing loss of FNI (Figure 2A). The AR for $\mathrm{N}$ balance was $3.31 \mathrm{~g} / \mathrm{kg}$ of FPCM, a potential of $21 \%$ reduction, which equated to $2,342 \mathrm{~kg} / \mathrm{yr}$ of $\mathrm{N}(\mathrm{N}$ balance of 11,105 vs. $8,763 \mathrm{~kg} / \mathrm{yr}$ for MaxI and MinN, respectively. Although FNI was reduced dramatically under MinN, a partial reduction of $\mathrm{N}$ balance up to $33 \%$ of AR had minimal effect $(-0.01$ \$FPCM; $33 \mathrm{~N}$, Table 1). More stringent restrictions, however, led to a rapidly increasing loss of in FNI (Figure 2B). Partial reduction in both $\mathrm{P}$ and $\mathrm{N}$ balances together up to $33 \%$ of their respective AR led to a loss FNI of $0.03 \$ / \mathrm{kg}$ of
FPCM), which was a greater reduction than when $\mathrm{P}$ and $\mathrm{N}$ balance were reduced separately.

\section{Feeding, Cropping, and Manure Management Practices}

Detailed components of incomes, expenses, and $\mathrm{P}$ and $\mathrm{N}$ imports and exports are shown in Table 2. Table 3 describes crops and nutrient management, and Table 4 describes feeding practices.

Wisconsin Case. Under MaxI, crop sale amounted to $0.09 \$ / \mathrm{g}$ of FPCM, and the cost of home-grown feeds and purchased feed was 0.10 and $0.04 \$ / \mathrm{kg}$ of FPCM, respectively (Table 2). Purchased fertilizers contributed almost twice as much as purchased feed to total P imports. However, milk (and animals) sales and crop sales contributed almost equally to $\mathrm{P}$ export. In regard to $\mathrm{N}$ balance, the main source of $\mathrm{N}$ was biological $\mathrm{N}$ fixation followed in relatively equal proportion by purchased feed and purchased fertilizer (Table 2). Milk (and animal) sales and crop sales contributed almost equally to the export of $\mathrm{N}$ from the farm. Relative to MaxI, reducing $\mathrm{P}$ balance by $33 \%$ of its $\mathrm{AR}(0.10 \mathrm{~g} /$ $\mathrm{kg}$ of FPCM, Table 1) was accomplished essentially by reducing $\mathrm{P}$ import as purchased feed by $13 \%(-0.16 \mathrm{~g} /$ $\mathrm{kg}$ of PFCM, Table 2) and increasing $\mathrm{P}$ export from the sale of crops by $0.15 \mathrm{~g} / \mathrm{kg}$ of FPCM ( $12 \%$ increase), which was made possible by adoption of crop rotations that required importing more $\mathrm{P}$ as fertilizer $(9 \%$ 
increase) while relying less on crops that fix N (20\% decrease) and a dramatic increase (50\%) in purchased $\mathrm{N}$ fertilizer. On the other hand, relative to MaxI, reducing $\mathrm{N}$ balance by $33 \%$ of its AR $(0.78 \mathrm{~g} / \mathrm{kg}$ of FPCM, Table 1) was accomplished not as much by altering crop sales, but rather by reducing import of purchased feed $\mathrm{N}$ (6\% decrease), and changing crop rotations toward less biological $\mathrm{N}$ fixation (14\% decrease) but greater reliance on purchased $\mathrm{N}$ fertilizer $(27 \%$ increase, Table 2). Relative to MaxI, reducing both $\mathrm{P}$ and $\mathrm{N}$ balances by $33 \%$ of their respective AR (33P-33N, Table 2) provoked changes in strategies similar in magnitude to those observed for 33P.

In all WI simulations, a relatively constant proportion of total crop production was sold (31 to $35 \%$; Table 3 ) and home-grown crops supplied a relatively constant proportion of the DM required to feed the herd (81 to 85\%; Table 4). However, compared with MaxI, reducing nutrient balances $(33 \mathrm{P}, 33 \mathrm{~N}$, and $33 \mathrm{P}-33 \mathrm{~N})$ led to a substantial reduction in alfalfa and an increase in corn grain and soybean both in crop rotation (Table 3 ) and the rations of the herd (Table 4). Reduction in $\mathrm{P}$ balance (33P and 33P-33N) was achieved also by a combination of exporting additional corn grain (Table 3 ), and by removing mineral phosphate and limiting the use of corn distillers grain in the diet (Table 4).

Québec Case. Under MaxI, crop sale amounted to $0.09 \$ / \mathrm{g}$ of FPCM, and the costs of home-grown feeds and purchased feeds were identical $(0.09 \$ / \mathrm{kg}$ of FPCM, Table 2). Purchased feeds contributed almost 4 times as much as purchased fertilizers to total $\mathrm{P}$ imports. However, the sale of milk (and animals) and crop sales contributed almost equally to $\mathrm{P}$ exports. In regard to $\mathrm{N}$ balance, purchased feed and fertilizer together contributed almost 4 times as much as biological fixation to total $\mathrm{N}$ imports (Table 2). Milk (and animal) sales and crop sales contributed almost equally to the export of $\mathrm{N}$ from the farm. Relative to MaxI, reducing P balance by $33 \%$ of its AR (0.18 g/ $\mathrm{kg}$ of FPCM, Table 1) was accomplished essentially by reducing $\mathrm{P}$ imports as purchased feed by $23 \%(-0.50$ $\mathrm{g} / \mathrm{kg}$ of FPCM, Table 2). This effect was, however, accompanied by a reduction in $\mathrm{P}$ exports from the sale of crops (10\% decrease, Table 2), and an increase in $\mathrm{P}$ import as fertilizer ( $38 \%$ increase, Table 2). On the other hand, relative to MaxI, reducing $\mathrm{N}$ balance by $33 \%$ of

Table 2. Income, expenses, imports, and exports of $\mathrm{P}$ and $\mathrm{N}$ in base simulations to maximize net income (MaxI), and when farm net income is maximized under partial reduction in nutrient balance: $33 \%$ of the achievable reduction in $\mathrm{P}(33 \mathrm{P}), \mathrm{N}(33 \mathrm{~N})$, and both $\mathrm{P}$ and $\mathrm{N}$ simultaneously (33P-33N) for Wisconsin and Québec dairy farm cases

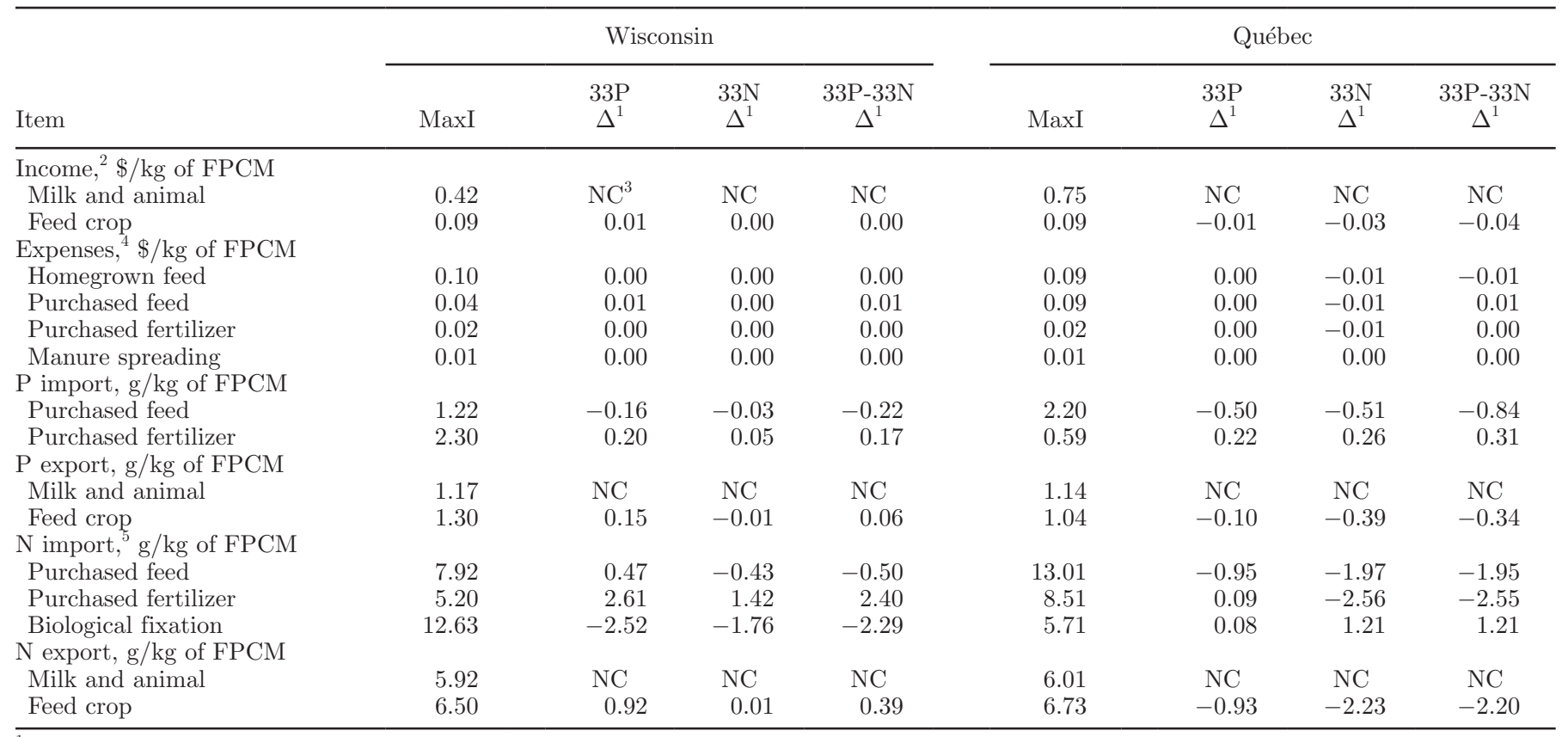

${ }^{1} \Delta=$ simulation $_{\mathrm{i}}-$ MaxI, where $\mathrm{i}=33 \mathrm{P}, 33 \mathrm{~N}$, or $33 \mathrm{P}-33 \mathrm{~N}$.

${ }^{2}$ Annual milk sold in Wisconsin and Québec was 946,631 and 707,399 kg/yr of fat- and protein-corrected milk (FPCM), respectively.

${ }^{3} \mathrm{NC}=$ no changes because milk and animal sold are variables that are not optimized in N-CyCLES (nutrient cycling: crops, livestock, environment, and soil).

${ }^{4}$ Additional expenses included fixed and other variable costs: 0.232 and $0.506 \$ / \mathrm{kg}$ of FPCM for Wisconsin and Québec, respectively.

${ }^{5}$ Additional $\mathrm{N}$ import included $6 \mathrm{~kg} / \mathrm{ha}$ of atmospheric deposition (NADP, 2016), which equated to 0.958 and $1.204 \mathrm{~g} / \mathrm{kg}$ of $\mathrm{FPCM}$ for the Wisconsin and Québec, respectively. 
Table 3. Rotations, crops, purchased fertilizer, and manure nutrient sold in base simulations to maximize net income (MaxI), and when farm net income was maximized under partial reduction in nutrient balance: $33 \%$ of the achievable reduction in $\mathrm{P}(33 \mathrm{P}), \mathrm{N}(33 \mathrm{~N})$, and both $\mathrm{P}$ and $\mathrm{N}$ together $(33 \mathrm{P}-33 \mathrm{~N})$ for Wisconsin and Québec dairy farm cases

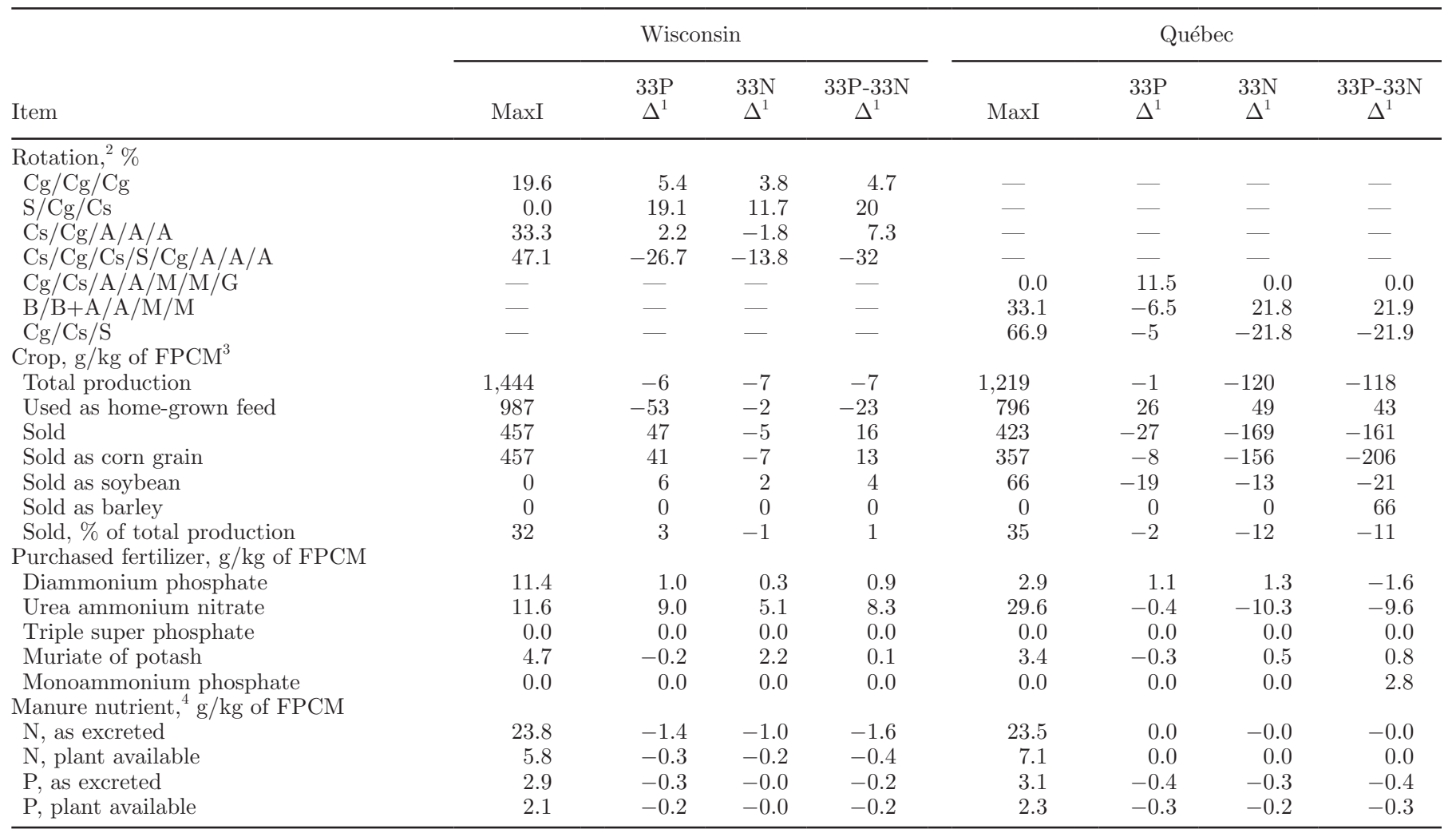

${ }^{1} \Delta=$ simulation $_{\mathrm{i}}-\mathrm{MaxI}$, where $\mathrm{i}=33 \mathrm{P}, 33 \mathrm{~N}$, or $33 \mathrm{P}-33 \mathrm{~N}$.

${ }^{2} \mathrm{Cs}=$ corn silage; $\mathrm{Cg}=$ corn grain; $\mathrm{B}=$ barley; $\mathrm{A}=$ alfalfa; $\mathrm{M}=$ mixed alfalfa and grass (silage); $\mathrm{G}=$ grass $($ hay) $\mathrm{S}=$ soybean; $\mathrm{B}+\mathrm{A}=$ first year alfalfa established with barley (cover crop).

${ }^{3} \mathrm{FPCM}=$ fat- and protein-corrected milk.

${ }^{4}$ Manure $\mathrm{N}$ and $\mathrm{P}$ excretion (urine + feces) for MaxI simulation was 30.6 and $7.8 \mathrm{t} / \mathrm{yr}$ for Wisconsin and 21.4 and $6.2 \mathrm{t} / \mathrm{yr}$ for Quebec, respectively.

its AR (1.09 g/kg of FPCM, Table 1) was accomplished by reducing $\mathrm{N}$ imports as purchased feed and fertilizer ( 2 and $30 \%$, respectively) and changing crop rotations toward increasing biological $\mathrm{N}$ fixation ( $21 \%$ increase) and (counter intuitively) reducing in $\mathrm{N}$ exports from crop sales (33\% reduction). Relative to MaxI, reducing both $\mathrm{P}$ and $\mathrm{N}$ balance by $33 \%$ of their respective $\mathrm{AR}$ (33P-33N, Table 2) drastically affected both the feeding strategy ( $\mathrm{P}$ and $\mathrm{N}$ import in the form of purchased feed decrease 38 and 15\%, respectively), and the cropping strategy (import as purchased fertilizer increased $54 \%$ for P but decreased $30 \%$ for N, whereas biological $\mathrm{N}$ fixation increase 21\%). However, the exports of $\mathrm{P}$ and $\mathrm{N}$ as crops sold decreased substantially $(33 \%$ for both; Table 2).

In all QC simulations, crops supplied a relatively constant proportion of the DM required to feed the herd (64 to $68 \%$; Table 4), but the proportion of total crop production sold (35 and 32\% for MaxI and
33P) decreased substantially when the objective was to reduce $\mathrm{N}$ balance $(23$ and $24 \%$ for $33 \mathrm{~N}$ and $33 \mathrm{P}-$ $33 \mathrm{~N}$; Table 3). Furthermore, the detailed operational changes revealed substantial differences in cropping (Table 3) and feeding strategies (Table 4) depending on whether the goal was to reduce $\mathrm{P}$ or $\mathrm{N}$ balance. The reduction in $\mathrm{P}$ balance was achieved primarily by dietary changes including the replacement of wheat and corn distillers grain with soyhull and alterative protein sources (Table 4). Crop rotations were changed slightly toward a reduction of soybean produced as crop for sale (Table 3). On the other hand, the reduction in $\mathrm{N}$ balance was achieved through a substantial replacement of the 3-yr corn-soybean rotation with the 5-yr barleyalfalfa rotation accompanied by reductions in sales of corn grain and soybeans and (Table 3) and substantial changes in herd rations. Specifically, a substantial shift occurred among home-grown feed toward more alfalfa silage, mixed silage, corn grain, and barley at the ex- 
pense of corn silage and soybean, whereas purchased feeds moved away from wheat and distillers grain and toward brewers grain and grass hay (Table 4).

\section{Interaction Between $P$ and $N$ Balances}

Figure 3 was built to display the $\mathrm{AR}$ for $\mathrm{P}$ and $\mathrm{N}$ balances (horizontal lines) and to visualize the interactions between $\mathrm{P}$ and $\mathrm{N}$ balances in the $\mathrm{WI}$ and $\mathrm{QC}$. The range in $\mathrm{P}$ balance did not overlap between WI and QC (Figure 3B). However, there was a substantial overlap in $\mathrm{N}$ balances between the 2 regional cases (Figure $3 \mathrm{~A}$ ). In WI, stepwise reductions in $\mathrm{P}$ balance had a biphasic effect on $\mathrm{N}$ balance. Reducing $\mathrm{P}$ balance up to $50 \%$ of its AR (up to $0.9 \mathrm{~g} / \mathrm{kg}$ of FPCM) was accompanied by a decrease in $\mathrm{N}$ balance, but greater $\mathrm{P}$ balance reduction led to substantial increases in $\mathrm{N}$ balance (Figure
3B). However, for QC, stepwise reductions in $\mathrm{P}$ balance consistently led to increases in corresponding $\mathrm{N}$ balance. For its part, reductions in $\mathrm{N}$ balance in WI led to slight increases in $\mathrm{P}$ balance except when $\mathrm{N}$ balance was approaching its lower limit. In QC, reducing $\mathrm{N}$ balance consistently and substantially increased $\mathrm{P}$ balance (Figure 3A).

\section{Sensitivity Analysis}

Positive or negative changes in feed or fertilizer prices had little effects on FNI for both WI and QC, except for an increase in FNI of $0.03 \$ / \mathrm{kg}$ of FPCM when feed price increased by $35 \%$ for the WI (Table 5 ). In both regional cases, increasing fertilizer prices by $25 \%$ or decreasing feed prices by $35 \%$ had little effect on the change in FNI associated with $33 \mathrm{P}, 33 \mathrm{~N}$, and $33 \mathrm{P}-33 \mathrm{~N}$

Table 4. Feeding (home-grown and purchased feeds, $\mathrm{g} / \mathrm{kg}$ of fat- and protein-corrected milk, FPCM) in base simulations to maximize net income (MaxI) and when farm net income is maximized under partial reduction in nutrient balance: $33 \%$ of the achievable reduction in $\mathrm{P}$ (33P), $\mathrm{N}$ $(33 \mathrm{~N})$, and both $\mathrm{P}$ and $\mathrm{N}$ simultaneously $(33 \mathrm{P}-33 \mathrm{~N})$ for Wisconsin and Québec dairy farm cases

\begin{tabular}{|c|c|c|c|c|c|c|c|c|}
\hline \multirow[b]{2}{*}{ Item } & \multicolumn{4}{|c|}{ Wisconsin } & \multicolumn{4}{|c|}{ Québec } \\
\hline & MaxI & $\begin{array}{c}33 \mathrm{P} \\
\Delta^{1}\end{array}$ & $\begin{array}{c}33 \mathrm{~N} \\
\Delta^{1}\end{array}$ & $\begin{array}{c}33 \mathrm{P}-33 \mathrm{~N} \\
\Delta^{1}\end{array}$ & MaxI & $\begin{array}{c}33 \mathrm{P} \\
\Delta^{1}\end{array}$ & $\begin{array}{c}33 \mathrm{~N} \\
\Delta^{1}\end{array}$ & $\begin{array}{c}33 \mathrm{P}-33 \mathrm{~N} \\
\Delta^{1}\end{array}$ \\
\hline \multicolumn{9}{|c|}{ Home-grown feed, $\mathrm{g} / \mathrm{kg}$ of FPCM } \\
\hline Corn silage & 467.0 & 0.0 & 0.0 & 0.0 & 501.1 & 0.0 & -115.1 & -115.3 \\
\hline Alfalfa silage & 257.9 & -59.2 & -42.5 & -52.2 & 91.0 & 6.1 & 42.2 & 42.3 \\
\hline Mixed silage & 158.1 & -36.3 & -26.1 & -32.0 & 129.6 & 4.5 & 60.1 & 60.2 \\
\hline Grass (hay) & 0.0 & 0.0 & 0.0 & 0.0 & 0.0 & 6.4 & 0.0 & 0.0 \\
\hline Soybean & 27.2 & 8.2 & 8.2 & 8.5 & 33.6 & 9.2 & -9.3 & -3.6 \\
\hline Corn grain, ground & 76.8 & 34.5 & 58.7 & 52.5 & 0.0 & 5.8 & 52.4 & 87.3 \\
\hline Barley grain & 0.0 & 0.0 & 0.0 & 0.0 & 40.7 & -5.7 & 18.9 & -27.6 \\
\hline \multicolumn{9}{|c|}{ Purchased feed, $\mathrm{g} / \mathrm{kg}$ of FPCM } \\
\hline Grass (hay) & 19.8 & 9.0 & 9.0 & 9.0 & 105.5 & 19.3 & 25.7 & -73.6 \\
\hline Soybean & 8.2 & -8.2 & -8.2 & -8.2 & 0.0 & 0.0 & 0.0 & 0.0 \\
\hline Corn grain, ground & 0.0 & 0.0 & 0.0 & 0.0 & 0.0 & 0.0 & 0.0 & 0.0 \\
\hline Barley, rolled & 0.0 & 0.0 & 0.0 & 0.0 & 172.0 & 2.8 & -29.1 & -172.0 \\
\hline Wheat & 0.0 & 0.0 & 0.0 & 0.0 & 16.1 & -16.1 & -16.1 & -16.1 \\
\hline Brewers grain & 0.0 & 0.0 & 0.0 & 0.0 & 7.0 & -7.0 & 45.5 & -7.0 \\
\hline Calcium soap of fat & 0.0 & 0.0 & 0.0 & 0.0 & 0.0 & 0.0 & 2.4 & 0.0 \\
\hline $\mathrm{SBM},{ }^{2}$ expeller & 0.0 & 0.0 & 0.0 & 0.0 & 0.0 & 0.0 & 0.0 & 0.0 \\
\hline SBM, solvent & 0.0 & 0.0 & 0.0 & 0.0 & 0.0 & 0.0 & 0.0 & 0.0 \\
\hline Corn gluten meal & 2.4 & 5.8 & -0.8 & 5.8 & 0.0 & 0.0 & 0.0 & 0.0 \\
\hline Corn distiller grain & 130.1 & -35.7 & 0.0 & -45.0 & 138.1 & -62.6 & -88.0 & -136.1 \\
\hline Blood meal & 0.0 & 0.0 & 0.0 & 0.0 & 0.0 & 9.7 & 4.7 & 16.2 \\
\hline Urea & 0.1 & 0.07 & 0.0 & 0.003 & 0.8 & 0.4 & -0.7 & 0.12 \\
\hline Soy hull & 0.0 & 78.1 & 0.0 & 52.3 & 0.0 & 29.1 & 7.2 & 337.0 \\
\hline Cottonseed & 0.0 & 4.06 & 4.06 & 9.6 & 0.0 & 0.0 & 0.0 & 0.0 \\
\hline Beet sugar & 0.0 & 0.0 & 0.0 & 0.0 & 0.0 & 0.0 & 0.0 & 0.0 \\
\hline $\mathrm{CaCO}_{3}$ & 5.43 & -0.86 & -0.71 & -0.68 & 5.36 & -0.52 & -0.64 & -4.24 \\
\hline $\mathrm{NaH}_{2} \mathrm{PO}_{4} \cdot \mathrm{H}_{2} \mathrm{O}$ & 5.74 & -5.72 & -5.72 & -5.61 & 0.0 & 0.0 & 0.0 & 2.87 \\
\hline $\mathrm{MgO}$ & 0.02 & 0.02 & 0.02 & 0.02 & 0.03 & 0.01 & -0.00 & 0.02 \\
\hline $\mathrm{CaSO}_{4} \cdot 2 \mathrm{H}_{2} \mathrm{O}$ & 0.06 & -0.02 & -0.01 & -0.01 & 0.29 & 0.49 & -0.05 & 2.69 \\
\hline $\mathrm{NaCl}$ & 0.07 & 0.20 & -0.01 & 0.24 & 3.93 & 0.32 & 1.26 & 0.53 \\
\hline $\mathrm{MgSO}_{4} \cdot 7 \mathrm{H}_{2} \mathrm{O}$ & 5.07 & -0.12 & -1.27 & -0.23 & 0.0 & 0.0 & 0.27 & 0.68 \\
\hline Total, $\mathrm{g} / \mathrm{kg}$ of FPCM & 1,164 & -6 & -5 & -6 & 1,245 & 2 & 2 & -6 \\
\hline Home grown, \% & 85 & -4 & 0 & -2 & 64 & 2 & 4 & 4 \\
\hline Purchased, \% & 15 & 4 & 0 & 2 & 36 & -2 & -4 & -4 \\
\hline
\end{tabular}

${ }^{1} \Delta=$ simulation $_{\mathrm{i}}-$ MaxI, where $\mathrm{i}=\mathrm{MinP}, \mathrm{MinN}, 33 \mathrm{P}, 33 \mathrm{~N}$, or 33P-33N.

${ }^{2} \mathrm{SBM}=$ soybean meal. 

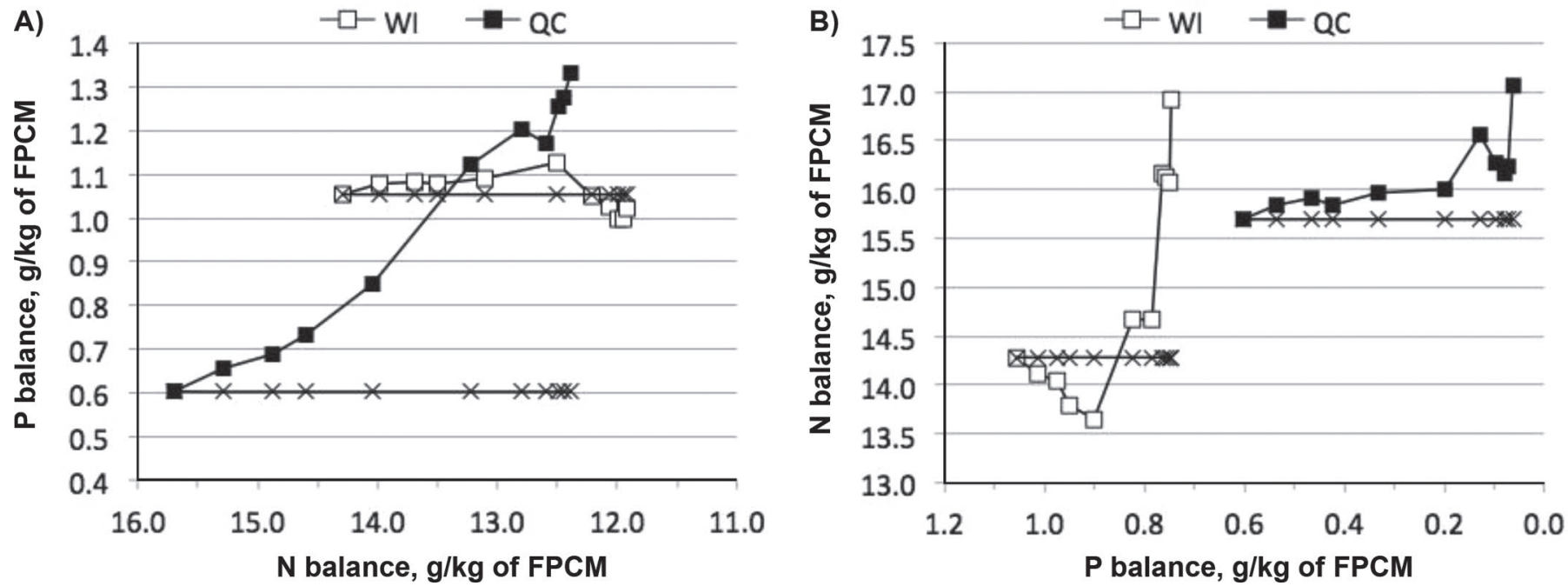

Figure 3. Effect of reducing $\mathrm{N}$ balance on $\mathrm{P}$ balance (A) and effect of reducing $\mathrm{P}$ balance on $\mathrm{N}$ balance (B). Stepwise reduction in nutrient balance was $0,12.5,25,33,50,75,87.5,93.75,96.875,98.438$, and $99.9 \%$ of achievable reduction, which is depicted by the horizontal line marked with an $\times$ going from left to right, respectively, and where the furthest point to the left is the balance when the objective is to maximize net income $(0 \%$ reduction) and the minimum balance is indicated by the point furthest to the right (99.9\% reduction). FPCM $=$ fat- and proteincorrected milk; QC = Québec; WI = Wisconsin.

relative to the initial MaxI simulation results. In contrast, decreasing fertilizer prices by $25 \%$ or increasing feed prices by $35 \%$ had distinct effects between the 2 cases. For all partial reduction simulations $(33 \mathrm{P}, 33 \mathrm{~N}$, and $33 \mathrm{P}-33 \mathrm{~N})$, a lower extent of FNI reduction was present in WI, but a greater extent of FNI reduction in QC (Table 5). In the case of 33P, these effects may be explained by the aforementioned finding that the strategy to reduce $\mathrm{P}$ balance included a slight increase in crop export (and thus an increase in revenues associated with the sale of crops) in WI, but a decrease in crop export in QC. In the case of 33N, this effect may be due to a combination of small changes in feeding and cropping strategies for WI, but appeared to be linked to a decrease in revenue associated with the sale of crops for QC (Table 2).

\section{DISCUSSION}

\section{Units of Whole-Farm Nutrient Balance}

In this study, whole-farm nutrient balances were expressed per kilogram of FPCM, which was a departure from the more common and traditional approach of expressing whole-farm nutrient balance per hectare of cropland. The latter has been used as an environmental impact indicator (especially when the concern is regional water quality), whereas the former has emerged as the unit of preference in life cycle analysis for greenhouse gases emissions (a global atmospheric concern). Some authors have kept these respective assessments with their respective units (Klootwijk et al., 2016), but others have begun to calculate whole-farm

Table 5. Effect of variation in concentrate feed and fertilizer prices on maximum net income (MaxI, $\$ / \mathrm{kg}$ of fat- and protein-corrected milk; FPCM), and variation in net income (\% of MaxI) when net income is maximized under the constraint of partial reduction in nutrient balance: $33 \%$ of the achievable reduction for $\mathrm{P}(33 \mathrm{P}), \mathrm{N}(33 \mathrm{~N})$, and both $\mathrm{N}$ and $\mathrm{P}$ simultaneously (33P-33N) in Wisconsin and Québec dairy farm cases

\begin{tabular}{|c|c|c|c|c|c|c|c|c|}
\hline \multirow[b]{2}{*}{ Price situation } & \multicolumn{4}{|c|}{ Wisconsin } & \multicolumn{4}{|c|}{ Québec } \\
\hline & MaxI & $\begin{array}{c}33 \mathrm{P} \\
\Delta^{1}\end{array}$ & $\begin{array}{c}33 \mathrm{~N} \\
\Delta^{1}\end{array}$ & $\begin{array}{c}33 \mathrm{P}-33 \mathrm{~N} \\
\Delta^{1}\end{array}$ & MaxI & $\begin{array}{c}33 \mathrm{P} \\
\Delta^{1}\end{array}$ & $\begin{array}{c}33 \mathrm{~N} \\
\Delta^{1}\end{array}$ & $\begin{array}{c}33 \mathrm{P}-33 \mathrm{~N} \\
\Delta^{1}\end{array}$ \\
\hline Initial situation & 0.12 & -8 & -3 & -9 & 0.11 & -4 & -10 & -30 \\
\hline Fertilizer prices: $+25 \%$ & 0.12 & -8 & -4 & -10 & 0.10 & -5 & -9 & -31 \\
\hline Feed prices: $-35 \%$ & 0.11 & -7 & -4 & -9 & 0.12 & -6 & -9 & -27 \\
\hline Fertilizer prices: $-25 \%$ & 0.13 & -6 & -2 & -6 & 0.11 & -7 & -10 & -38 \\
\hline Feed prices: $+35 \%$ & 0.15 & -3 & -1 & -3 & 0.11 & -5 & -17 & -47 \\
\hline
\end{tabular}

${ }^{1} \Delta=$ simulation $_{\mathrm{i}}-$ MaxI (variation in $\%$ of MaxI), where $\mathrm{i}=33 \mathrm{P}, 33 \mathrm{~N}$, or $33 \mathrm{P}-33 \mathrm{~N}$. 
nutrient balance per kilogram of FPCM as an indicator of farm-level nutrient use efficiency for milk production (Cela et al., 2014, 2017). The functional unit is important to consider as researchers seek ways to assess environmental impacts of systems intensification and identify dairy management practices that combine high milk performance with low environmental impact (Salou et al., 2017). These authors suggested also that a combination of units might be more revealing than a single unit of assessment. In this study, however, milk sold $(946,631$ and 707,399 $\mathrm{kg}$ of PFCM in WI and QC, respectively) and hectares of land (151 and 142 ha in WI and QC, respectively) were model inputs that were kept constant in all simulations. Thus results presented here can be converted readily to a per hectare basis. For example, the $\mathrm{P}$ and $\mathrm{N}$ balance data presented in Table $1(1.05 \mathrm{~g}$ of $\mathrm{P} / \mathrm{kg}$ of PFCM and $14.29 \mathrm{~g} / \mathrm{kg}$ of FPCM for WI, respectively, and $0.60 \mathrm{~g}$ of $\mathrm{P} / \mathrm{kg}$ of PFCM and $15.7 \mathrm{~g} / \mathrm{kg}$ of FPCM for QC, respectively) correspond to balances of $6.6 \mathrm{~g}$ of $\mathrm{P} / \mathrm{ha}$ and $90 \mathrm{~g}$ of $\mathrm{N} /$ ha in WI compared with $3.0 \mathrm{~g}$ of $\mathrm{P} /$ ha and $78 \mathrm{~g}$ of $\mathrm{N} / \mathrm{ha}$ in QC. These per hectare balances were similar to those reported in recent studies of dairy farms in the state of New York (Cela et al., 2014; Soberon et al., 2015).

\section{Whole-Farm Nutrient Utilization Efficiency}

As found in many other studies (Nielsen and Kristensen, 2005; Hristov et al., 2006; Soberon et al., 2015), our results highlighted that purchased feed and fertilizers were the most important factors that affected whole-farm $\mathrm{P}$ and $\mathrm{N}$ balances. The relative contribution of purchased feed $\mathrm{N}$, purchased fertilizer $\mathrm{N}$, and biological $\mathrm{N}$ fixation to total $\mathrm{N}$ import was, however, a major difference between WI and QC. Model-predicted efficiency of utilization of $\mathrm{P}$ at the farm level in this study (output/input from Table 2) was 70, 73, 70, and $73 \%$ under MaxI, 33P, 33N, and 33P-33N, respectively, in WI and $78,83,71$, and $81 \%$ under MaxI, 33P, 33N, and $33 \mathrm{P}-33 \mathrm{~N}$, respectively, in QC. These values were somewhat higher than the range found in the literature from balance studies conducted on commercial dairy farms. Spears et al. (2003a), Hristov et al. (2006), and Cela et al. (2014) reported whole-farm P efficiency of 66, 63, and 61\%, respectively. However, Plaizier et al. (2014), Gourley et al. (2012), and Roberts et al. (2008) reported values as low as 48,35 , and $21 \%$, respectively. Simulation models have predicted whole-farm $\mathrm{P}$ balance ranging from $44 \%$ (Huhtanen et al., 2011) to $92 \%$ (Belflower et al., 2012) and even up to 96\% (Huhtanen et al., 2011).

Model predicted efficiency of utilization of $\mathrm{N}$ at the farm level in this study (output/input from Table 2) was $48,51,50$, and $51 \%$ under MaxI, 33P, 33N, and
$33 \mathrm{P}-33 \mathrm{~N}$, respectively, in WI and $47,45,41$, and $41 \%$ under MaxI, 33P, 33N, and 33P-33N, respectively, in QC. These efficiencies were higher than the values obtained from on-farm data collection $(21,41$, and $38 \%$ in Spears et al., 2003b; Hristov et al., 2006; and Cela et al., 2014, respectively), but similar to the $54 \%$ reported in Belflower et al. (2012). Compared with data collected on farms, the higher efficiencies reported here may reflect the potential gains from following standard nutritional and NMP practices and from considering feeding, cropping, and nutrient management as a single unit of management. Nutrient mass balance can be reduced over time using a holistic approach to farm management including precision feeding, meticulous manure allocation, and fertilizer management (Cela et al., 2015; Soberon et al., 2015; Cela et al., 2017). A second explanation for the high $\mathrm{P}$ and $\mathrm{N}$ efficiencies of our study may be related to the higher proportion of home-grown crop sold in our regional cases (Table 3) compared with the aforementioned commercial farms studies. Compared with exporting nutrients in the form of crop sold, the transformation of feed to milk (or BW gain) by the animals on the farm adds an inevitable loss of efficiency. Thus, given that the system boundaries of our model was set at the farm gate, the whole-farm $\mathrm{P}$ and $\mathrm{N}$ efficiency would be expected to increase with an increase in the portion of the home-grown crops sold. The importance of interpreting results in light of the system boundaries cannot be understated as ignoring of nutrient losses of purchased inputs artificially elevated on-farm efficiencies of intensive farms relying on large amounts of external inputs as illustrated in the work of Spears et al. (2003a,b). Authors have suggested that selling crops improves $\mathrm{N}$ use efficiency because nutrient export is not limited by the physiology of the dairy cow (Roberts et al., 2008). Furthermore, Rotz et al. (2002) suggested that producing grain crops for sale improves economic resiliency (i.e., decrease annual variation in net return) and improved FNI when straw as a coproduct was harvested and used as bedding.

\section{Animal Units Per Hectare}

From a nutrient management perspective, a study conducted in WI suggested that 1.85 and 3.70 animal units (AU) per ha of cropland as critical pivot points, above which manure $\mathrm{P}$ and manure $\mathrm{N}$, respectively, exceed the recycling potential of the crops (Saam et al., 2005). In the case of $\mathrm{P}$, a higher value (2.4 AU/ ha) was reported recently for farms in the state of New York (Cela et al., 2014). In comparison, AU per hectare were low in this study (1.39 and 1.24 in WI and QC, respectively), suggesting that on-farm manure nutrient production was insufficient to meet crop requirements 
and substantial amounts of fertilizers had to be imported (Table 3). In contrast to farms with large herd size relative to available land, which export manure nutrient (Hristov et al., 2006; Cela et al., 2014), this study highlighted that low animal density (AU/ha) allowed for the development of cropping strategies that not only can easily recycle manure nutrients, but also allowed to grow crops for sale, which in turn provided a degree of flexibility to accommodate for strategic management objectives. In our study, the higher availability of land per cow in QC compared with WI may have contributed to the higher $\mathrm{AR}$ for both $\mathrm{P}$ and $\mathrm{N}$ balances in the former compared with the latter (Figure $3)$; however, numerous factors affect whole-farm nutrient balance and their changes over time (Soberon et al., 2015; Cela et al., 2017).

\section{Economic Versus Environmental Outcomes}

Although other studies have indicated the feasibility of improving simultaneously economic and environmental outcomes (Rotz et al., 2002; Mihailescu et al., 2015), in this study, partial reductions of $\mathrm{P}$ and $\mathrm{N}$ balances had either negligible or negative effects on the FNI in both WI and QC. This result was due in part to the parameterization of N-CyCLES with the best feeding and nutrient management practices, hence precluding the quantification of benefits from adopting best management practices. As used in this study, the N-CyCLES model simply explored the reallocation of resources under different management objectives. In doing so, our results suggested that substantial reductions in nutrient balance (up to $33 \%$ of $\mathrm{AR}$ for both $\mathrm{P}$ and N) can be achieved with minimal negative effect on FNI. Furthermore, to our knowledge few simulation tools are available to study systematically the interactions between $\mathrm{P}$ and $\mathrm{N}$ balances. Exploration of such relationships are important, however, as the literature has provided evidence of pollution swapping (i.e., an increase of a pollutant as a result of a taking action to reduce another pollutant; Stevens and Quinton, 2009). Our results suggested different types of interactions depending on the production system. Up to a point, reduction in $\mathrm{P}$ balance was accompanied by a reduction in $\mathrm{N}$ balance in WI but not in QC (Figure 3).

\section{CONCLUSIONS}

Considering feeding, manure, and crop management as a single unit of management, the N-CyCLES model allowed to identify unique $\mathrm{AR}$ in whole-farm $\mathrm{P}$ and $\mathrm{N}$ balances for dairy farms typical of WI and QC. Results of our analysis suggested up to $33 \%$ of AR in both $\mathrm{P}$ and $\mathrm{N}$ whole-farm balances are feasible with minimal effect on FNI when feeding and cropping strategies are considered together rather than optimizing herd nutrition (using NRC standards) and crop fertilization (by following local NMP regulations) as independent units of management. Depending on the farm situation, the model identified both synergetic and antagonistic patterns of change in the balance of one nutrient in relation to the other.

\section{ACKNOWLEDGMENTS}

The authors thank Guy Allard (Université Laval, Quebec, QC, Canada), Sally Flis (Fertilizer Institute, Washington, DC), and Vinicius Moreira (Louisiana State University, Baton Rouge) for their contributions to the earlier development of the model.

\section{REFERENCES}

ASAE. 2005. Manure production and characteristics. ASAE Standards D384.2, American Society of Agriculture Engineers (ASAE), St. Joseph, MI.

Belflower, J. B., J. K. Bernard, D. K. Gattie, D. W. Hancock, L. M. Risse, and C. A. Rotz. 2012. A case study of the potential environmental impacts of different dairy production systems in Georgia. Agric. Syst. 108:84-93. https://doi.org/10.1016/j.agsy 2012.01.005.

Berentsen, P. B. M., and G. W. J. Giesen. 1995. An environmentaleconomic model at farm level to analyse institutional and technical change in dairy farming. Agric. Syst. 49:153-175. https://doi.org/ 10.1016/0308-521X(94)00042-P.

Bouwman, L., K. K. Goldewijk, K. W. Van Der Hoek, A. H. W. Beusen, D. P. Van Vuuren, J. Willems, M. C. Rufino, and E. Stehfest. 2013. Exploring global changes in nitrogen and phosphorus cycles in agriculture induced by livestock production over the 1900-2050 period. Proc. Natl. Acad. Sci. USA 110:20882-20887. https://doi .org/10.1073/pnas.1012878108.

CDP (Center for Dairy Profitability). 2009. Milk production costs in 2008 on selected Wisconsin dairy farms. Accessed Jul. 19, 2013. http://cdp.wisc.edu/pdf/08cost.pdf.

CDP (Center for Dairy Profitability). 2011. Milk production costs in 2009 on selected Wisconsin dairy farms. Accessed Jul. 19, 2013. http://cdp.wisc.edu/pdf/09cost.pdf.

Cela, S., Q. M. Ketterings, K. Czymmek, M. Soberon, and C. Rasmussen. 2014. Characterization of nitrogen, phosphorus, and potassium mass balances of dairy farms in New York State. J. Dairy Sci. 97:7614-7632. https://doi.org/10.3168/jds.2014-8467.

Cela, S., Q. M. Ketterings, K. Czymmek, M. Soberon, and C. Rasmussen. 2015. Long-term trends of nitrogen and phosphorus mass balances on New York State dairy farms. J. Dairy Sci. 98:7052-7070. https://doi.org/10.3168/jds.2015-9776.

Cela, S., Q. M. Ketterings, M. Soberon, C. Rasmussen, K. J. Czymmek, and Q. M. Ketterings. 2017. Upper Susquehanna watershed and New York State improvements in nitrogen and phosphorus mass balances of dairy farms. J. Soil Water Conserv. 72:1-11. https://doi.org/10.2489/jswc.72.1.1.

CRAAQ. 2009a. AGDEX 732-821m, Ensilage de foin préfané en silo tour, Frais de récolte, de conservation et de reprise, Septembre 2006, corrigé Octobre 2006, révisé Mars 2009. Centre de référence en agriculture et agroalimentaire du Québec, Québec, Canada. 6 pp.

CRAAQ. 2009b. AGDEX 732-821j, Foin en balles rectangulaires entreposées pêle-mêle, Frais de récolte, de conservation et de reprise. Septembre 2006, révisé Février 2009. Centre de référence en agriculture et agroalimentaire du Québec, Québec, Canada. 6 pp. 
CRAAQ. 2010a. Guide de référence en fertilisation. 2nd ed. Centre de référence en agriculture et agroalimentaire du Québec (CRAAQ), Québec, Canada. 473 pp.

CRAAQ. 2010b. AGDEX 111-821a, Maïs fourrager, Budget à l'hectare, Octobre 2011. Centre de référence en agriculture et agroalimentaire du Québec, Québec, Canada. 4 pp.

CRAAQ. 2010c. AGDEX 111-821b, Maïs-grain, Budget à l'hectare, Novembre 2010. Centre de référence en agriculture et agroalimentaire du Québec, Québec, Canada. 5 pp.

CRAAQ. 2010d. AGDEX 112-821b, Blé alimentation animale, Budget à l'hectare, Novembre 2010. Centre de référence en agriculture et agroalimentaire du Québec, Québec, Canada. 6 pp.

CRAAQ. 2010e. AGDEX 113-821a, Avoine d'alimentation animale, Budget à l'hectare, Novembre 2010. Centre de référence en agriculture et agroalimentaire du Québec, Québec, Canada. 6 pp.

CRAAQ. 2010f. AGDEX 114-821a, Orge d'alimentation animale, Budget à l'hectare, Novembre 2010. Centre de référence en agriculture et agroalimentaire du Québec, Québec, Canada. 6 pp.

CRAAQ. 2010g. AGDEX 141-821, Soya, Budget à l'hectare, Décembre 2010. Centre de référence en agriculture et agroalimentaire du Québec, Québec, Canada. 6 pp.

CRAAQ. 2011a. AGDEX 412.61/890b, Entreprise laitière-Maïs fourrager 2009, Analyse de données AGRITEL. Centre de référence en agriculture et agroalimentaire du Québec, Québec, Canada. 4 pp.

CRAAQ. 2011b. AGDEX 540-855, Fertilisants et amendements, Prix, Juin 2011. Centre de référence en agriculture et agroalimentaire du Québec, Québec, Canada. 1 pp.

CRAAQ. 2011c. AGDEX 149-821, Canola, Budget à l'hectare, Janvier 2011. Centre de référence en agriculture et agroalimentaire du Québec, Québec, Canada. 5 pp.

CRAAQ. 2012a. AGDEX 121/821. Foin de luzerne et de mil avec plante-abri. Références économiques. AGDEX 120/821. Janvier 2012. Centre de référence en agriculture et agroalimentaire du Québec, Québec, Canada. 7 pp.

CRAAQ. 2012b. AGDEX 121/821. Foin de luzerne et de mil sans plante-abri. Références économiques. AGDEX 121/821. Janvier 2012. Centre de référence en agriculture et agroalimentaire du Québec, Québec, Canada. 6 pp.

FADQ (Financière Agricole de Québec). 2012. Rendements de référence 2012 en assurance récolte. Accessed Apr. 20, 2012. http:// www.fadq.qc.ca/fileadmin/fr/cent_docu/docu_publ/stat/asrec/ rend_refe/rend_refe_2012.pdf.

Ghebremichael, L. T., P. E. Cerosaletti, T. L. Veith, C. A. Rotz, J M. Hamlett, and W. J. Gburek. 2007. Economic and phosphorusrelated effects of precision feeding and forage management at a farm scale. J. Dairy Sci. 90:3700-3715. https://doi.org/10.3168/ jds.2006-836.

Giasson, E., R. B. Bryant, and N. L. Bills. 2002. Environmental and economic optimization of dairy manure management: A mathematical programming approach. Agron. J. 94:757-766. https://doi .org/10.2134/agronj2002.7570.

Gould, B. W. 2014. Understanding dairy market. University of Wisconsin Dairy Marketing and Risk Management Program. Milk prices. Accessed Jun. 10, 2016. http://future.aae.wisc.edu/data/ annual_values/by_area/10.

Gourley, C. J. P., S. R. Aarons, and J. M. Powell. 2012. Nitrogen use efficiency and manure management practices in contrasting dairy production systems. Agric. Ecosyst. Environ. 147:73-81. https:// doi.org/10.1016/j.agee.2011.05.011.

Hristov, A. N., W. Hazen, and J. W. Ellsworth. 2006. Efficiency of use of imported nitrogen, phosphorus, and potassium and potential for reducing phosphorus imports on Idaho dairy farms. J. Dairy Sci. 89:3702-3712. https://doi.org/10.3168/jds.S0022-0302(06)72411 $-0$.

Huhtanen, P., J. Nousiainen, and E. Turtola. 2011. Dairy farm nutrient management model: 2. Evaluation of different strategies to mitigate phosphorus surplus. Agric. Syst. 104:383-391. https://doi .org/10.1016/j.agsy.2011.01.001

IDF (International Dairy Federation). 2015. A common carbon footprint approach for dairy. The IDF guide to standard life cycle assessment methodology for the dairy sector. IDF Bulletin 479 .
International Dairy Federation, Brussels, Belgium. Accessed Jun. 10, 2016. https://store.fil-idf.org/product/a-common-carbon -footprint-approach-for-the-dairy-sector-the-idf-guide-to-standard -life-cycle-assessment-methodology/?free_file_download.

Klootwijk, C. W., C. E. Van Middelaar, P. B. M. Berentsen, and I. J. M. de Boer. 2016. Dutch dairy farms after milk quota abolition: Economic and environmental consequences of a new manure policy. J. Dairy Sci. 99:8384-8396. https://doi.org/10.3168/ jds.2015-10781.

Koelsch, R. 2005. Evaluating livestock system environmental performance with whole-farm nutrient balance. J. Environ. Qual. 34:149-155. https://doi.org/10.2134/jeq2005.0149.

Koelsch, R., and G. Lesoing. 1999. Nutrient balance on Nebraska livestock confinement systems. J. Anim. Sci. 77:63-71.

Laboski, C. A. M., J. B. Peters, and L. G. Bundy. 2006. Nutrient application guidelines for field, vegetable, and fruit crops in Wisconsin. UW-Extension publication A2809. Accessed Jun. 10, 2016. http://learningstore.uwex.edu/assets/pdfs/A2809.pdf.

Massey, R. E. 2008. Manure distribution cost analyzer: A spreadsheet program. Accessed Jun. 10, 2016. http://agebb.missouri.edu/ commag/crops/massey/downloads/Manure\%20Distribution\%20 Cost\%20Analyzer.xls.

MDDELCC. (Ministère du Développement Durable, de l'Environnement et de la Lutte contre les Changements Climatiques). 2015. Guide de référence du Règlement sur les exploitations agricoles. Accessed Jun. 10, 2016. http://www.mddelcc.gouv .qc.ca/milieu_agri/agricole/guide-reference-REA.pdf.

Mihailescu, E., W. Ryan, P. N. C. Murphy, I. A. Casey, and J. Humphreys. 2015. Economic impacts of nitrogen and phosphorus use efficiency on nineteen intensive grass-based dairy farms in the South of Ireland. Agric. Syst. 132:121-132. https://doi.org/10 .1016/j.agsy.2014.09.008.

NADP (National Atmospheric Deposition Program). 2016. Ammonia Monitoring Network. Accessed Jun. 10, 2016. http://nadp.sws .uiuc.edu/AMoN

Nennich, T. D., J. H. Harrison, L. M. VanWieringen, D. Meyer, A. J. Heinrichs, W. P. Weiss, N. R. St-Pierre, R. L. Kincaid, D. L. Davidson, and E. Block. 2005. Prediction of manure and nutrient excretion from dairy cattle. J. Dairy Sci. 88:3721-3733. https://doi .org/10.3168/jds.S0022-0302(05)73058-7.

Nielsen, A. H., and I. S. Kristensen. 2005. Nitrogen and phosphorus surpluses on Danish dairy and pig farms in relation to farm characteristics. Livest. Sci. 96:97-107. https://doi.org/10.1016/j .livprodsci.2005.05.012.

NRC. 2001. Nutrient Requirements of Dairy Cattle. 7th ed. Natl Acad. Press, Washington, DC.

Plaizier, J. C., G. Legesse, K. H. Ominski, and D. Flaten. 2014 Whole-farm budgets of phosphorus and potassium on dairy farms in Manitoba. Can. J. Anim. Sci. 94:119-128. https://doi.org/10 .4141/cjas2013-089.

Posner, J. L., J. O. Baldock, and J. L. Hedtcke. 2008. Organic and conventional production systems in the Wisconsin integrated cropping systems trials: I. Productivity 1990-2002. Agron. J. 100:253-260. https://doi.org/10.2134/agrojnl2007.0058.

Powell, J. M., D. B. Jackson-Smith, and L. D. Satter. 2002. Phosphorus feeding and manure nutrient recycling on Wisconsin dairy farms. Nutr. Cycl. Agroecosyst. 62:277-286. https://doi.org/10 .1023/A:1021265705737.

Roberts, C. J., D. H. Lynch, R. P. Voroney, R. C. Martin, and S. D. Juurlink. 2008. Nutrient budgets of Ontario organic dairy farms. Can. J. Soil Sci. 88:107-113. https://doi.org/10.4141/S06-056.

Rotz, C. A., M. S. Corson, D. S. Chianese, F. Montes, S. D. Hafener, H. F. Bonifacio, and C. U. Coiner. 2015. The Integrated Farm System Model, Reference Manual version 4.2. Accessed Jun. 10, 2016. http://www.ars.usda.gov/Main/docs.htm?docid=8519 \#Reference.

Rotz, C. A., G. W. Roth, and W. L. Stout. 2002. Economic and environmental implications of small grain production and use on Pennsylvania dairy farms. Appl. Eng. Agric. 18:417-428. https:// doi.org/10.13031/2013.8752. 
Saam, H., J. M. Powell, D. B. Jackson-Smith, W. L. Bland, and J. L. Posner. 2005. Use of animal density to estimate manure nutrient recycling ability of Wisconsin dairy farms. Agric. Syst. 84:343-357. https://doi.org/10.1016/j.agsy.2004.06.020.

Salou, T., C. Le Mouël, and H. M. G. van Der Werf. 2017. Environmental impacts of dairy system intensification: The functional unit matters! J. Clean. Prod. 140:445-454. https://doi.org/10.1016/j. jclepro.2016.05.019.

Schils, R. L. M., M. H. A. de Haan, J. G. A. Hemmer, A. van den Polvan Dasselaar, J. A. de Boer, A. G. Evers, G. Holshof, J. C. van Middelkoop, and R. L. G. Zom. 2007. DairyWise, a whole-farm dairy model. J. Dairy Sci. 90:5334-5346. https://doi.org/10.3168/ jds.2006-842.

Soberon, M. A., S. Cela, Q. M. Ketterings, C. N. Rasmussen, and K. J. Czymmek. 2015. Changes in nutrient mass balances over time and related drivers for 54 New York State dairy farms. J. Dairy Sci. 98:5313-5329. https://doi.org/10.3168/jds.2014-9236.

Spears, R. A., R. A. Kohn, and A. J. Young. 2003b. Whole-farm nitrogen balance on Western dairy farms. J. Dairy Sci. 86:4178-4186. https://doi.org/10.3168/jds.S0022-0302(03)74033-8.

Spears, R. A., A. J. Young, and R. A. Kohn. 2003a. Whole-farm phosphorus balance on Western dairy farms. J. Dairy Sci. 86:688-695. https://doi.org/10.3168/jds.S0022-0302(03)73648-0.
Stevens, C. J., and J. N. Quinton. 2009. Policy implications of pollution swapping. Phys. Chem. 34:589-594. https://doi.org/10.1016/ j.pce.2008.01.001.

USDA. 2011. Wisconsin Agricultural Statistics. Accessed Jun. 9 2016. https://www.nass.usda.gov/Statistics_by_State/Wisconsin/ Publications/Annual_Statistical_Bulletin/bulletin2011_web.pdf

USDA. 2013. Fertilizer Use and Price. Accessed Feb. 25, 2014. http:// www.ers.usda.gov/data-products/fertilizer-use-and-price.aspx.

Valacta. 2011. Stats 2010 National statistics. Accessed Jan. 30, 2014 http://www.valacta.com/EN/publications/Pages/dairy-evolution aspx.

Wang, S. J., D. G. Fox, D. J. R. Cherney, L. E. Chase, and L. O. Tedeschi. 2000. Whole-herd optimization with the Cornell Net Carbohydrate and Protein system. III. Application of an optimization model to evaluate alternatives to reduce nitrogen and phosphorus mass balance. J. Dairy Sci. 83:2160-2169. http://dx.doi.org/ https://doi.org/10.3168/jds.S0022-0302(00)75099-5.

WIDATCP (Wisconsin Department of Agriculture Trade and Consumer Protection). 2014. Nutrient Management. Accessed Feb. 25, 2014. http://datcp.wi.gov/Farms/Nutrient_Management/index .aspx\#regulations.

\section{APPENDIX}

Table A1. Feeds and feed prices $(\$ / t$ of $\mathrm{DM})$ for Wisconsin $\left(\mathrm{WI}^{1}\right)$ and Québec $\left(\mathrm{QC}^{1}\right)$ cases

\begin{tabular}{|c|c|c|c|c|}
\hline \multirow[b]{2}{*}{ Code $^{2}$} & \multirow[b]{2}{*}{ Feed name } & \multicolumn{2}{|c|}{ Feed price } & \multirow[b]{2}{*}{ Limits $^{3}$} \\
\hline & & WI & $\mathrm{QC}$ & \\
\hline \multicolumn{5}{|c|}{ Home grown, sold, or purchased } \\
\hline $\mathrm{CoSi}-35$ & Corn silage & 110 & 95 & 40 \\
\hline AlSi-83 & Alfalfa silage & 205 & 174 & \\
\hline $\mathrm{MxSi}-74 / 71$ & Mixed silage $^{4}$ & 157 & 152 & \\
\hline GrHy-52 & Grass hay & 160 & 154 & 10 \\
\hline SB-w-108 & Soybean seed, whole & 425 & 444 & \\
\hline CoGr-27 & Corn grain, ground & 200 & 253 & 40 \\
\hline Barley-8 & Barley, rolled & 171 & 199 & 20 \\
\hline Wheat-116 & Wheat, rolled & 262 & 232 & 20 \\
\hline \multicolumn{5}{|c|}{ Purchased feed only } \\
\hline Brewers- 16 & Brewers grains & 353 & 267 & \\
\hline Canola-19 & Canola meal & 346 & 375 & \\
\hline FatCa-40 & Calcium soap of fat ${ }^{5}$ & 1.100 & 1.531 & 2.5 \\
\hline SBMx-104 & Soybean meal, expeller & 524 & 734 & \\
\hline SBM48-107 & Soybean meal, solvent & 387 & 511 & \\
\hline CGM-25 & Corn gluten meal & 618 & 786 & \\
\hline CoDi-23 & Corn distiller grain ${ }^{5}$ & 181 & 242 & 15 \\
\hline BldMl-14 & Blood meal $^{4}$ & 1,026 & 616 & 5 \\
\hline Urea & Urea & 631 & 867 & 1.5 \\
\hline SoyHull-103 & Soy hull & 225 & 247 & 10 \\
\hline CottonSd-37 & Cottonseed $^{5}$ & 288 & - & 20 \\
\hline $\mathrm{CaCO}_{3}$ & Calcium carbonate & 253 & 281 & \\
\hline $\mathrm{NaH}_{2} \mathrm{PO}_{4} \cdot \mathrm{H}_{2} \mathrm{O}$ & Sodium phosphate & 705 & 784 & \\
\hline $\mathrm{MgO}$ & Magnesium oxide & 690 & 767 & \\
\hline $\mathrm{CaSO}_{4} \cdot 2 \mathrm{H}_{2} \mathrm{O}$ & Calcium sulfate & 455 & 505 & \\
\hline $\mathrm{NaCl}$ & Sodium chloride & 321 & 357 & 3.5 \\
\hline $\mathrm{MgSO}_{4} \cdot 7 \mathrm{H}_{2} \mathrm{O}$ & Magnesium sulfate & 546 & 607 & \\
\hline
\end{tabular}

${ }^{1}$ Median prices representative of the 2008-2012 period from Gould (2014) and the Penn State extension feed price list for WI and from the Valacta (Sainte-Anne-de-Bellevue, Québec, Canada) database for QC.

${ }^{2}$ When present, the number associated with a feed code indicates the feed entry number in the NRC (2001) feed composition tables.

${ }^{3}$ Upper limits in ration DM.

${ }^{4}$ Chemical composition of mixed silage was as per NRC (2001) table entry 74 and 71 for WI and QC, respectively.

${ }^{5}$ Feeds used in ration of lactating animals only. 
Table A2. Fertilizers and fertilizer prices $(\$ / t)$ for Wisconsin (WI) and Québec (QC) cases

\begin{tabular}{llcc}
\hline & & \multicolumn{2}{c}{ Price $^{1}$} \\
\cline { 3 - 4 } Code & Feed name & WI & QC \\
\hline $18-46-0$ & Diammonium phosphate & 755 & 831 \\
$27-0-0$ & Urea ammonium nitrate & 381 & 610 \\
$0-46-0$ & Triple super phosphate & 715 & 904 \\
$0-0-60$ & Muriate of potash & 700 & 721 \\
$11-52-0$ & Monoammonium phosphate & 755 & 830 \\
\hline
\end{tabular}

${ }^{1}$ From USDA (2013) for WI and from CRAAQ (2011b) for QC.

Table A3. Rotations, N, P, K recommendations, biological N-fixation, P removal, and cost of production for Wisconsin (WI) and Québec (QC) cases

\begin{tabular}{|c|c|c|c|c|c|c|c|c|c|c|}
\hline \multirow[b]{2}{*}{ Item } & \multicolumn{5}{|c|}{ WI rotations ${ }^{1}$} & \multicolumn{5}{|c|}{ QC rotations ${ }^{1}$} \\
\hline & 1 & 2 & 3 & 4 & 5 & 1 & 2 & 3 & 4 & 5 \\
\hline \multicolumn{11}{|l|}{ Rotation years $^{2}$} \\
\hline 1 & $\mathrm{Cg}$ & $\mathrm{Cg}$ & Cs & Cs & Cs & Cs & Cs & $\mathrm{Cg}$ & B & $\mathrm{Cg}$ \\
\hline 2 & & $\mathrm{Cs}$ & $\mathrm{Cg}$ & $\mathrm{Cg}$ & $\mathrm{Cg}$ & B & $\mathrm{Cg}$ & $\mathrm{Cs}$ & $\mathrm{A}^{3}$ & $\mathrm{Cs}$ \\
\hline 3 & & $\mathrm{~S}$ & $\mathrm{~A}$ & $\mathrm{Cs}$ & $\mathrm{Cs}$ & $\mathrm{A}^{3}$ & $\mathrm{~S}$ & $\mathrm{~A}$ & A & $\mathrm{S}$ \\
\hline 4 & & & A & $\mathrm{S}$ & $\mathrm{S}$ & A & W & $\mathrm{A}$ & M & \\
\hline 5 & & & $\mathrm{~A}$ & $\mathrm{Cg}$ & W & M & & M & M & \\
\hline 6 & & & & $\mathrm{~A}$ & A & M & & M & & \\
\hline 7 & & & & A & A & G & & G & & \\
\hline 8 & & & & $\mathrm{~A}$ & $\mathrm{~A}$ & & & & & \\
\hline $\mathrm{N},{ }^{4} \mathrm{~kg} / \mathrm{ha}$ & 179 & 104 & 29 & 57 & 43 & 64 & 116 & 76 & 33 & 115 \\
\hline $\mathrm{P}_{2} \mathrm{O}_{5}{ }^{4} \mathrm{~kg} / \mathrm{ha}$ & 101 & 94 & 98 & 97 & 92 & 51 & 51 & 50 & 51 & 47 \\
\hline $\mathrm{K}_{2} \mathrm{O}{ }^{4} \mathrm{~kg} / \mathrm{ha}$ & 112 & 145 & 199 & 179 & 179 & 151 & 104 & 152 & 151 & 113 \\
\hline $\mathrm{BNF},{ }^{5} \mathrm{~kg} / \mathrm{t}$ & 0.0 & 24.7 & 115.1 & 86.4 & 86.4 & 39.1 & 11.6 & 42.9 & 54.7 & 15.5 \\
\hline P-rvl, ${ }^{6} \mathrm{~kg} / \mathrm{ha}$ & 25.1 & 31.2 & 32.7 & 32.2 & 30.7 & 16.6 & 17.2 & 17.8 & 15.4 & 19.8 \\
\hline Cost, ${ }^{7} \$ /$ ha & 801 & 561 & 528 & 536 & 515 & 263 & 423 & 366 & 226 & 559 \\
\hline
\end{tabular}

${ }^{1} \mathrm{Cs}=$ corn silage; $\mathrm{Cg}=$ corn grain; $\mathrm{B}=$ barley; $\mathrm{A}=$ alfalfa; $\mathrm{M}=$ mixed alfalfa and grass (silage); $\mathrm{G}=$ grass (hay); $\mathrm{S}=$ soybean; $\mathrm{W}=$ wheat.

${ }^{2}$ Crop grown in each successive years of a rotation; for example, in the case of WI rotation 1 is a 1-yr rotation (monoculture) of corn but rotation 5 requires $8 \mathrm{yr}$ for completion, including $3 \mathrm{yr}$ of corn followed by $1 \mathrm{yr}$ of soybean followed by $1 \mathrm{yr}$ of wheat and finally $3 \mathrm{yr}$ of alfalfa.

${ }^{3}$ First year alfalfa established with barley.

${ }^{4}$ Recommended fertilization for land unit $\mathrm{E}$ (lowest $\mathrm{OM}$, and lowest soil test of $\mathrm{P}$ and $\mathrm{K}$ ).

${ }^{5}$ Biological N-fixation (BNF) was 66 and $40 \%$ of crop N yield for alfalfa and soybean, respectively (Laboski et al., 2006).

${ }^{6} \mathrm{P}$-rvl is the average $\mathrm{P}$ removal for the entire rotation in land unit $\mathrm{E}$.

${ }^{7}$ Rotation average calculated from CDP (2011) for the WI and using data from CRAAQ (2009a,b, 2010b,c,d,e,f,g, 2011c, 2012a,b) and FADQ (2012) for the QC, excluding fertilization costs (purchased fertilizers and manure spreading costs), but including farm income stabilization insurance reimbursement for barley, corn grain, soybean, and wheat (for QC only). 
Appendix Figure A1: Objective functions for farm net income, $\mathrm{P}$ balance and $\mathrm{N}$ balance.

Equation 1: Farm net income $=$ Incomes - Expenses, where:

$$
\begin{aligned}
\text { Incomes } & =\mathrm{Ms} \times \mathrm{P}+\mathrm{As} \times \mathrm{P}+\sum_{i=1}^{10} \mathrm{Cp}-\mathrm{Cl}-\mathrm{Cf}_{i} \times \mathrm{P}_{i} \\
\text { Expenses } & =\mathrm{Vc}+\mathrm{Fc}+\sum_{j=1}^{5} \mathrm{Ro}_{j} \times \mathrm{Pc}_{j}+\sum_{k=1}^{27} \mathrm{Fp}_{k} \times \mathrm{P}_{k}+\sum_{k=1}^{27} \mathrm{Cf}+\mathrm{Fp}_{k} \times \mathrm{Sc}_{k}+\sum_{k=1}^{27}\left[\mathrm{Cp}-\mathrm{Cl}-\mathrm{Cf}+\mathrm{Fp}_{k} \times \mathrm{Tc}_{k}\right. \\
& +\sum_{l=1}^{5} \mathrm{Fe}_{l} \times \mathrm{P}+\mathrm{SpC}_{l}+\sum_{m=1}^{2} \mathrm{Mu}_{m} \times \mathrm{SpC}_{m}+\sum_{m=1}^{2} \mathrm{Me}_{m} \times \mathrm{Ec}_{m}
\end{aligned}
$$

Equation 2: $\mathrm{P}$ balance $=\mathrm{P}$ importation $-\mathrm{P}$ exportation, where:

$$
\begin{aligned}
& \mathrm{P} \text { importation }=\sum_{k=1}^{27} \mathrm{Fp}_{k} \times[\mathrm{P}]_{k}+\sum_{l=1}^{5} \mathrm{Fe}_{l} \times[\mathrm{P}]_{l}+\sum_{m=1}^{2} \mathrm{Mi}_{m} \times[\mathrm{P}]_{m} \\
& \mathrm{P} \text { exportation }=\mathrm{Ms} \times[\mathrm{P}]+\mathrm{As} \times[\mathrm{P}]+\sum_{i=1}^{10} \mathrm{Cp}-\mathrm{Cl}-\mathrm{Cf}_{i} \times[\mathrm{P}]_{i}+\sum_{m=1}^{2} \mathrm{Me}_{m} \times[\mathrm{P}]_{m}
\end{aligned}
$$

Equation 3: $\mathrm{N}$ balance $=\mathrm{N}$ importation $-\mathrm{N}$ exportation, where:

$\mathrm{N}$ importation $=\sum_{k=1}^{27} \mathrm{Fp}_{k} \times[\mathrm{N}]_{k}+\sum_{l=1}^{5} \mathrm{Fe}_{l} \times[\mathrm{N}]_{l}+\sum_{m=1}^{2} \mathrm{Mi}_{m} \times[\mathrm{N}]_{m}$

$\mathrm{N}$ exportation $=\mathrm{Ms} \times[\mathrm{N}]+\mathrm{As} \times[\mathrm{N}]+\sum_{i=1}^{10} \mathrm{Cp}-\mathrm{Cl}-\mathrm{Cf}{ }_{i} \times[\mathrm{N}]_{i}+\sum_{m=1}^{2} \mathrm{Me}_{m} \times[\mathrm{N}]_{m}$

\section{Indices:}

$\mathrm{I}=$ Crop, $\mathrm{i}=1$ to 9

$\mathbf{J}=$ Rotation, $\mathbf{j}=1$ to 5

$\mathrm{K}=$ Feed, $\mathrm{k}=1$ to 26

$\mathrm{L}=$ Fertilizer, $1=1$ to 5

$\mathrm{M}=$ Manure, $\mathrm{m}=1$ to 2

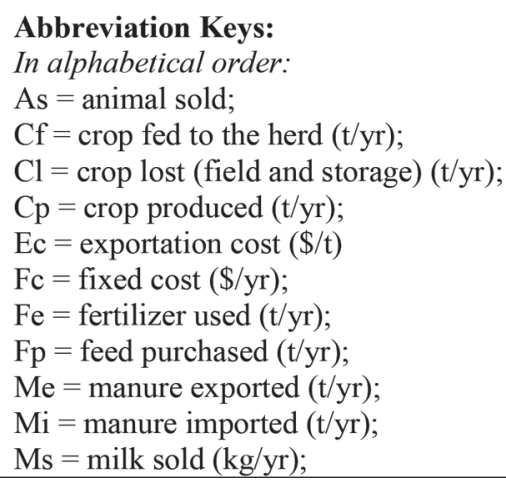

$\mathrm{Mu}=$ manure used $(\mathrm{t} / \mathrm{yr})$;

$[\mathrm{N}]=\mathrm{N}$ concentration $(\mathrm{kg} / \mathrm{t})$

$\mathrm{P}=$ price of milk $(\$ / \mathrm{kg})$, animal $(\$ / \mathrm{yr})$, crop

$(\$ / t)$, feed $(\$ / t)$ or fertilizer $(\$ / t)$;

$[\mathrm{P}]=\mathrm{P}$ concentration $(\mathrm{kg} / \mathrm{t})$

$\mathrm{Pc}=$ production cost $(\$ / \mathrm{ha})$;

Ro $=$ rotation distribution $(\mathrm{ha} / \mathrm{yr})$;

$\mathrm{Sc}=$ storage cost $(\$ / \mathrm{tr})$;

$\mathrm{SpC}=$ spreading cost $(\$ / \mathrm{tr})$

$\mathrm{Tc}=$ transport cost $(\$ / \mathrm{tr})$;

$\mathrm{Vc}=$ variable cost $(\$ / \mathrm{yr})$;

Figure A1. Objective functions for farm net income, $\mathrm{P}$ balance, and $\mathrm{N}$ balance. 